\title{
Relationships between the Big-5 Model and Effectuation versus Causation Logics of Entrepreneurs in New Ventures: The Estonian IT Sector
}

\author{
Dafnis N. Coudounaris $1,2, *$ (iD and Henrik G.S. Arvidsson ${ }^{2}$ \\ 1 Aalborg University Business School, Aalborg University, 9220 Aalborg, Denmark \\ 2 School of Economics and Business Administration, University of Tartu, 51009 Tartu, Estonia; \\ henrik.arvidsson@oriontransport.ee \\ * Correspondence: daco@business.aau.dk
}

check for updates

Citation: Coudounaris, Dafnis N., and Henrik G.S. Arvidsson. 2021. Relationships between the Big-5 Model and Effectuation versus Causation Logics of Entrepreneurs in New Ventures: The Estonian IT Sector. Administrative Sciences 11: 106 https://doi.org/10.3390/ admsci11040106

Received: 21 August 2021 Accepted: 15 September 2021 Published: 23 September 2021

Publisher's Note: MDPI stays neutral with regard to jurisdictional claims in published maps and institutional affiliations.

Copyright: (c) 2021 by the authors. Licensee MDPI, Basel, Switzerland. This article is an open access article distributed under the terms and conditions of the Creative Commons Attribution (CC BY) license (https:/ / creativecommons.org/licenses/by/ $4.0 /)$.

\begin{abstract}
This study aims to investigate the influence of the big- 5 personality traits on causation and effectuation decision-making logics using the entrepreneurial process theory. This is an empirical study based on 113 surveys of managers/entrepreneurs from the Estonian IT sector. The questionnaire was uploaded onto the online platform of connect.ee and the participants were invited to complete it. The study reveals that only conscientiousness positively and significantly predicts causation logic. However, four of the five factors of personality traits positively and significantly predict effectuation logic, i.e., openness, conscientiousness, extraversion, agreeableness, except for neuroticism. Furthermore, only nine of 25 hypotheses are positive and significant, and of the 11 relationships of the model, three are negative and non-significant for causation logic and eight are negative and non-significant for effectuation logic. Finally, there are another five relationships of the model which are positively but non-significantly related. Managers of IT companies in Estonia should think of shifting to effectuation logic as most personality traits predict effectuation logic, and therefore, there is the possibility of a better performance for IT firms. Eight of the 51 items of the model had standardised regression weights below the threshold of 0.500 , but only four were extracted from the final model. The extraction of items from the model indicates the need for the re-identification of the constructs of personality traits using, for example, the six-factor personality traits.
\end{abstract}

Keywords: big-5 personality traits; causation logic; effectuation logic; entrepreneurial process theory; managers/entrepreneurs; Estonian IT sector

\section{Introduction}

The process in which firms expand their business abroad and the processes behind it represent an area that is both interesting and complex. The first theory that dealt with internationalisation was the Uppsala model launched by Johanson and Vahlne (1977). After that, the focus shifted from viewing the firm as a solitary unit to more of a network approach (Johanson and Vahlne 2009). The internationalization process itself has been challenged by the birth of so-called born-global firms and beyond.

The question of how managers make their decisions in the internationalisation process is the one that very few researchers have focused on (Coudounaris 1984; 2012, pp. 256-59; 2018; 2021; Coudounaris et al. 2009, p. 679; Leonidou et al. 2010, p. 88). Traditionally, researchers have assumed that companies act through the process of causation, but lately, that notion has been challenged. One theory that impacts the discourse (even if the theoretical framework is far from developed) is the theory of effectuation, presented by Saras D Sarasvathy. In her 2001 article "Causation and Effectuation: Toward a theoretical shift from economic inevitability to entrepreneurial contingency", she, to a certain extent, builds upon the theoretical framework once created by Cyert and March (1963).

A recent literature review on the topic of effectuation decision-making logic from 2017 to 2019 revealed that there has been an acceleration of publications in the field 
(Coudounaris and Arvidsson 2019), and a systematic literature review from Jan 2017 to March 2020 investigated the drivers of internationalisation strategy on the international performance of the firm, namely, effectuation, causation, and bricolage (Coudounaris and Arvidsson 2021). In addition, a study of ten international entrepreneurs revealed that the shift of decision-making logic happens through high effort processes, and attitudes towards a particular logic are formed through low-effort processes (Arvidsson et al. 2020, p. 1). Additionally, at an early stage, international entrepreneurs adopt causal logic, but later, because of their experience, they implement effectuation logic. Furthermore, a study of the internationalisation process, from the idea stage to the post-internationalisation stage, of an Estonian IT recruitment firm revealed that effectuation versus causation was chosen in terms of the expectations and perceptions of the future, and psychological factors appeared to play an important role rather than the actual events happening (Arvidsson and Coudounaris 2020, p. 1).

This study has the aim of examining the relationship between the personality traits of a corporate leader and the decision-making logic that $\mathrm{s} /$ he applies. The study is a nation-specific one that seeks to answer our questions in an Estonian setting.

A largely unresolved issue is finding a connection between personality traits and the adoption of decision-making logic, as according to Cervone and Pervin (2013), the most significant problem in personality psychology is the lack of a common taxonomy. The problem has recently been resolved with the creation of the five-factor model. This theory seeks to classify personality traits into five bipolar dimensions. John et al. (2008), McCrae and Costa (1987, 2008), Costa and McCrae (1992), Botwin and Buss (1989), and Jang et al. (1998) have paid attention to the five-factor model.

According to Simpeh (2011), "the trait model is still not supported by research evidence. The only way to explain or claim that it exists is to look through the lenses of one's characteristics/behaviours and conclude that one has the inborn quality to become an entrepreneur" (Simpeh 2011, p. 3). Therefore, the research gap of this study is that the trait model is still not supported by research evidence. Bearing in mind this research gap in the literature, the research question of this study is as follows: How do the five factors of personality traits associate with causation versus effectuation logics for entrepreneurs in a new venture, and which dimensions of personality traits are more influential on both decision-making logics? In addition, this study has three objectives, as follows: The first is to find whether the five-factor model of personality traits is good enough to predict both causation logic and effectuation logic in a new venture by an entrepreneur, or whether another model should be implemented in the future: for example, the six-factor model of personality traits of HEXACO (Ashton and Lee 2009; Lee and Ashton 2018) and the recently proposed model of Kerr et al. (2017, p. 25), who included the following personality traits of entrepreneurship in their complex process model of entrepreneurship: need for achievement, locus of control, self-efficacy, innovativeness, risk attitude, and the five-factor personality traits. The second objective is to determine whether the entrepreneur in a new venture should link the effect of his/her personality traits on the two decision-making logics and in future on the entrepreneurial process. The third objective is to ascertain what else can be done in future research.

The main contribution of this study is that it connects effectuation theory (Sarasvathy $2001,2009)$ to the five-factor model developed by McCrae and Costa $(1987,1999)$ and Costa and McCrae (1992) and entrepreneurship theory (Kerr et al. 2017; Simpeh 2011), in examining how the manager/entrepreneur's personality traits affect their decision-making logics. The main differences of the present study with other empirical studies is that it incorporates three theories-effectuation theory, psychological theory of personality characteristics (excluding risk taking, innovativeness, and tolerance for ambiguity introduced by Landstrom 1998), and entrepreneurship theory for a new venture. 


\section{Theoretical Framework and Literature Review}

\subsection{Theoretical Framework-The Entrepreneurial Process Theory}

In a systematic literature review of 116 articles, Davidsson and Gruenhagen (2021) argued that "the most popular and least defined way of referring to the studied process was 'entrepreneurial process' a term also found in many articles that were excluded from this review" (Davidsson and Gruenhagen 2021, pp. 1087-88). This popularity of the entrepreneurial process could stimulate future researchers to implement this process instead of using alternative processes, for example, the creation process, start-up process, formation process, emergence process, and entrepreneurship process. However, this study, due to the lack of a construct measuring the entrepreneurial process, implements the entrepreneurship theory for new ventures. According to Landström (1999) in psychological entrepreneurship theories the level of analysis is the individual. Simpeh (2011) argued that "these theories emphasized personal characteristics that defined entrepreneurship. Personality traits, locus of control and another three characteristics i.e., risk taking, innovativeness, and tolerance for ambiguity were associated with entrepreneurial inclination" (Simpeh 2011, p. 2). Baron and Markman (2018) argued that "During early phases of the entrepreneurial process, early entrepreneurs focus on activities as identifying opportunities, performing initial evaluations of the feasibility of the opportunities, and forming intentions to actually launch a new venture" (Baron and Markman 2018, p. 45). Dimov (2020, p. 27) developed a map of aspects of the entrepreneurial process, including entrepreneurial task (activities and people), time stance (externality and succession), and context (geography and innovation ecology). It is interesting to note that McMullen and Dimov (2013) developed the term "entrepreneurial journey", which includes different aspects such as novelty, information integration, and time (McMullen and Dimov 2013, p. 1491-93). In addition, there was an early discussion on "entrepreneurship process" by Moroz and Hindle (2012), who evaluated 32 published models on the entrepreneurship process. Moroz and Hindle (2012) argued that the evaluated models "were highly fragmented and insufficient for establishing an infrastructure upon which to synthesize an understanding of entrepreneurial process" (Moroz and Hindle 2012, p. 781).

Mets et al. (2013), based on three cases in Estonia, developed the entrepreneurial process-based learning and venture creation model, which was the training process. This process followed the logic of entrepreneurial process as previously described by Davidsson (2005) and Sarasvathy and Dew (2005), and included the following sub-processes/stages / actions: idea generation, opportunity recognition, opportunity development, and venture launch with different levels of differentiation of the stages (Mets et al. 2013, p. 112).

Recently, Mets et al. (2019) have examined the interconnections between entrepreneurial process, entrepreneurial journey, venture maturity, time, and space. Furthermore, Mets (2015) and Mets et al. (2019) suggested "replacing multiple dimensions of the entrepreneurial process by using the concept of maturity (of the process of venture creation) and process stages' outcomes (artefacts) as milestones and measures of that" (Mets 2021, p. 58). According to Mets's (2021) definition, "the entrepreneurial process is described by the stages' propositions, idea development, concept development and business development. Finally, the stages are linked in series with the entrepreneurial acts-outcomes of these stages, i.e., intention, new venture idea, opportunity confidence and finally, venture launch that can be understood as the decision to exploit the opportunity" (Mets 2021, p. 58). Mets (2021) suggested a modified version of the entrepreneurial process showing that "the maturity of the venture creation process becomes clear afterwards, i.e., after the launch of a business/product/project and the sustainable financial viability, or other similar event marking business operations, as a success of the process" (Mets 2021, p. 58). In addition, Trabskaia and Mets (2021) investigated the second stage of the entrepreneurial process, i.e., idea and opportunity, with the variables of feasibility and attractiveness in a sample of seven doctoral students attending an entrepreneurship course.

Metallo et al. (2021) in their study "explained the entrepreneurial process of new venture creation by stressing the unconscious mechanisms that govern entrepreneurs' 
behaviours" (Metallo et al. 2021, p. 35). This study focused on entrepreneurs and their attitudes. The present study links the entrepreneur/manager of a new venture with the effect of personality traits on effectuation versus causation logics using the entrepreneurial process theory. By doing so, the current study shows that the new venture creation process of entrepreneurs, whose psychological characteristics, i.e., personality traits, are important for understanding them (the definition of entrepreneurs is included in the notes) and will impact positively and significantly on both decision-making logics.

\subsection{Literature Review-Causation and Effectuation, and Other Aspects}

This section provides two to some extent bipolar decision-making models, namely, effectuation and causation. As we will discuss further, they are not genuinely bipolar, but can be used simultaneously or at different stages in a firm's development history, according to research.

\subsubsection{Causation}

Causation is a descriptive term that Saras D. Sarasvathy $(2001,2009)$ used to describe a traditional perspective on entrepreneurship (see notes at the end of the paper before the references for a definition of causation processes). When using a causation type of decision making, an individual decides on a predetermined goal and then selects between means to achieve that goal. Sarasvathy (2001) stated that entrepreneurship could be seen as a linear process, where entrepreneur volition leads to gestational and planning activities. Therefore, one can say that causation is ends-driven. Effectuation is the opposite of causation, namely, a decision-making logic that is means-driven.

In general, Philip Kotler (1991) is seen as the researcher who first described causal logic and one of its greatest proponents. He first stated that a company should analyse the long-term opportunities specifically for the market. Secondly, he argued for research into and selection of the target markets (segmentation). The third step was to design marketing strategies, the fourth step was to get involved in the planning of the marketing programs, and the final one was to implement and follow up the marketing efforts (Kotler 1991). Kotler adapted the causation approach in his model, and the process was referred to as the segmentation, targeting, and positioning process (Kotler 1991). Sarasvathy focused to a large extent on entrepreneurial firms operating in ambiguous market environments.

\subsubsection{Effectuation}

Effectuation dictates that target customers can only be defined as "ex-post" through whoever buys a product or service in uncertain and dynamic environments (see notes at the end of the paper before the references for a definition of effectuation processes). Goal changes are shaped and constructed over time and are sometimes formed by chance. Instead of focusing on goals, the entrepreneur focuses on the available set of means-the things over which the entrepreneur has control and what can be achieved using the set of means available (Sarasvathy 2001).

Traditionally, management theory has been built on the concept of causation, a decision-making model defined by Sarasvathy (2001) as:

"Causation processes take a particular effect as given and focus on selecting between means to create that effect" (Sarasvathy 2001, p. 245). Whilst Sarasvathy (2001) defines effectuation as: "Effectuation processes take a set of means as given and focus on selecting between possible effects that can be created with that set of means". (Sarasvathy 2001, p. 245)

Her theory is based on four basic principles (Sarasvathy 2001):

1. Affordable loss instead of expected returns.

2. Use of strategic alliances instead of analysing the competition.

3. The exploitation of contingencies instead of pre-existing knowledge.

4. Controlling the unpredictable future instead of predicting the future if it is uncertain. 
The underlying logic within effectuation theory is that, to the extent we can control the future, there is little or no need to predict it, since effectual logic is also used in situations where it is hard to analyse future events.

This is in contrast to the underlying meaning of causation decision making, which states that, to the extent we can predict the future, we can also control it. Sarasvathy (2001) states that an effectuation approach is more suitable when the future is uncertain, and the competence employed is skills in exploiting contingencies rather than knowledge. Additionally, in Sarasvathy's (2001) work, there is a conclusion that effectual decision making is means-driven, whilst causal decision making is ends-driven.

She also does not deny that decision makers can apply both causation and effectuation simultaneously, something that is also supported by Lam and Harker (2015) and CiszewskaMlinaric et al. (2016), whose main finding is that decision makers often simultaneously apply both logics. This conclusion is also shared by Dutta et al. (2015), who make the case that opportunities are discovered rather than created, and that causation and effectuation are present in emerging industries.

Both Kotler and Sarasvathy see managerial decisions as a process, but there are some differences. Kotler focuses on the means needed to achieve the desired outcome, whilst Sarasvathy focuses on what effect can be achieved with the means available. The logic is reversed, but the outcome is the same: namely, to maximise the outcome with the resources found (Sarasvathy 2001). As previously stated, the difference between the two approaches is how they handle the unknown or contingencies that occur along the way. Sarasvathy suggests that the higher the uncertainty, the greater the management team's chance to apply some effectuation logic in its decision-making process. This idea was questioned by Bridge (2021), who concludes that there is no correlation between uncertainty and entrepreneurial firms. She also focuses on the effectual network and co-creation between members of the network. The notion is that cooperation and co-creation are essential in entrepreneurial business, since smaller firms lack the resources to act alone in the market.

Effectual logic suggests that the future depends on the actions, inactions, or the actions of actors in the firms' environment. It also implies that the means provide the basis for the firm's decisions and, subsequently, new opportunities (Sarasvathy 2001, 2009; Kraaijenbrink et al. 2015).

As previously mentioned, partnerships and strategic alliances play a vital role in Sarasvathy's model. Moreover, successful entrepreneurs tend to opt for cooperation and building the market for the product in close or less close cooperation with customers, suppliers, and in some cases, together with direct or indirect competitors (Sarasvathy 2001, 2009). Sarasvathy concludes that firms in the early stages of their life favour effectuation over causation, as supported by Chandler et al. (2011) and Liu (2014), who conclude that small start-ups in general favour effectuation because they possess limited resources. This is a conclusion that both Chetty et al. (2015) and Schweizer (2015) challenge.

The above model shows three variables and how they together determine the nature of the venture. If a person, for instance, has worked 20 years as a truck driver and lacks higher education, the probability is higher than average that the person who identifies him- or herself as a truck driver will be more successful in the trucking business. The person already has at least in theory the skills needed to carry out his or her job, a suitable personality and knowledge base, and a relevant network. This sets the boundaries as well as creating opportunities when it comes to business. According to Sarasvathy (2001), the entrepreneur himself, his knowledge, and network are determinants when selecting the business area and the result if we remove the factor of contingencies.

According to the principles of effectuation, surprises can even be viewed as something positive if we leverage contingencies into new opportunities and ventures. Here, the entrepreneur's imagination, attitude, and satisfaction play a significant role and can be seen as the starting point for successful entrepreneurship (Sarasvathy 2009).

Another fundament in effectuation theory is the notion of continuous learning. As firms gain knowledge, they also tend to strive for changes in their effectual network: in the 
beginning, firms tend to cooperate with anyone interested in cooperation, but as their understanding of their environment increases, they instead strive to be more selective in their network partners. This means that the network also changes over time as the firm evolves into its more mature stages of existence (Sarasvathy 2001, 2009; Galkina and Chetty 2015).

\subsection{The Two Perspectives and the Current State of Relevant Research}

Sarasvathy's theory about effectual logic was a game-changer when it was first presented in 2001. Before that, the prevailing theory was causation, an ends-driven logic that implies that firms go through a lengthy process of analysing, planning, and implementing strategies to reach a pre-set goal. Sarasvathy's theory was at the other end of a bipolar spectrum. Her theory was not ends-driven but means-driven, meaning that the entrepreneur took a vantage point on what could be done with the resources at hand instead of focusing on the result or desired result. Although Sarasvathy makes an effective case for effectuation, she does not rule out that companies use causation as a decision-making process, meaning that it is likely that firms use a mix of the two. Nor does she argue that one of the two is superior to the other. Firms can also, to a degree, use a combination of the two in their managerial processes. The choices we make are often not conscious but occur in processes that are hidden from our consciousness.

There is a consensus among researchers that the application of either logic is not static, even if the question of why and how the shifts occur is a cause for major debate. Reymen et al. (2015) examined the dynamics of decision making and concluded that decision-making logic shifts and re-shifts over time and in scope depending on events in the firm's inner and outer environment and the firm's development, for example, market entry and the penetration of foreign markets.

Sarasvathy (2001) states that the main reason for shifts in the applied logic is uncertainty in the firm's environment and the number of resources owned by that organisation. Resources do not have to be tangible but can also be in the form of knowledge or network position. Resources can be "a new product or something in nature such as a lemon, it could be a service, a work of art, a minor irritation, a major problem, and an actionable idea" (Sarasvathy 2009, pp. 101-2). The more insecure and unpredictable environment, the more it favours effectuation over causation. This also works the other way around. The more predictable the environment becomes, the more the organisation favours causation, which has also been supported by Berends et al. (2014). Read and Sarasvathy (2005) also support her idea and state that as the firm grows and its knowledge increases, adopting causal logic becomes increasingly essential.

The question regarding the choice of decision-making logic still divides the researchers involved in management research. Sarasvathy (2001), Christensen et al. (2011), and Nummela et al. (2014) argue that there are periods where one or the other logic is more dominating. Other researchers, among them Chetty et al. (2014), Dutta et al. (2015), and CiszewskaMlinaric et al. (2016), argue for the simultaneous application of effectuation and causation. Smolka et al. (2018), who examined the correlation between effectual and causal logic and venture performance, concluded that ventures benefit from applying both logics.

There are also those making the case that the entrepreneur or manager is a factor when it comes to what logic is applied. Harms and Schiele (2012) state that the entrepreneur's experience is the main factor in the choice of applied logic, and that experienced entrepreneurs tend to favour effectuation before causation. Dew et al. (2015) add to this notion when they state that the more unpredictable the environment, the more critical is the entrepreneur's expertise. When it comes to experience, Dew et al. (2009) conclude that expert entrepreneurs prefer control-based strategies such as affordable loss instead of the more predictive strategies applied by less experienced entrepreneurs.

This makes a case for diverging behaviours between countries and regions, something that has not been fully analysed, as according to Matalamäki (2017), effectuation is a field of study that has still not reached its mature stage. This raises the question of why has more research not been devoted to the entrepreneur as a psychological being? Perhaps the 
answer is that although a vast amount of research has been conducted, the initial focus and interest have not been directed at these issues.

Velu and Jacob (2016) examined the relationship between personality, business model, and innovative capabilities. They concluded that managers with entrepreneurial traits are an asset to the firm's creative ability. Laskovaia et al. (2017) support this idea. They conclude that entrepreneurial reasoning is shaped by traits and the cultural context in which the firm operates. This conclusion challenges the basic assumption that Sarasvathy (2001) once presented that firms in uncertain environments tend to favour effectuation. If personal traits and cultural context are factors to be considered, what influence do they exert? Pfeffer and Khan (2018) also concluded that decision making is an issue highly connected to the personality of the entrepreneur, making the connection to personality but not to the five-factor model.

This also contradicts the findings of Engel et al. (2014), who, similarly to Sarasvathy (2001), concludes that inexperienced entrepreneurs adopt causal logic even if the future is to a high degree unpredictable. Liu (2014) comes up with a slightly more generic conclusion that small start-ups tend to favour effectuation and are generally means-driven. Liu also argues that limited resources force the entrepreneur to adopt an effectual approach.

Most of the research is based on the notion that entrepreneurs, in general, possess a particular set of skills. The problem with this line of reasoning is that entrepreneurs are individuals with different sets of traits, and the question is, therefore, whether all entrepreneurs have a set of predetermined traits of personality that can be categorised as "entrepreneurial" or whether there is a divergence even among entrepreneurs that makes them opt for different decision-making logics and use different sets of strategies.

\subsection{Personality Traits and the Five-Factor Personality Traits Model}

In psychology, there has been a long-standing battle between those such as acclaimed American psychologist Carl Rogers $(1957,1959,1967)$ and modern-day scientists such as DeYoung et al. (2010), who believe our personality is something inherited, with DeYoung et al. (2010, 2014), DeYoung (2015), and Allen and DeYoung (2017) even concluding that there are certain parts of the brain that are associated with different personality traits; and those who adopt the view that we are formed by external factors (Margolin et al. 2018). This is an argument that has been ongoing for the most part in clinical psychology, but it also has implications for organisational and behavioural psychology. Today, most researchers agree that personality is something that is, for the most part, encoded in us from birth (Lieberman 2016; Ciccarelli and White 2017).

When it comes to bridging effectuation theory and personality, not much has been done. Most of the research in terms of finding a correlation between personality and entrepreneurship has been performed on identifying traits that can be common for entrepreneurs as a group (Baum et al. 2001). Zhao and Seibert (2006) found a substantial difference in personality traits between entrepreneurs and managers.

One factor that has been greatly overlooked is the personality traits of the entrepreneur. His or her traits and the impacts on the "choice" of logic and the nature of the decisions taken are of great interest when it comes to an understanding of how an entrepreneur "chooses" logic and what kind of decisions are made.

There have been at least two attempts to define personality traits: the five-factor model (McCrae and Costa 1987, 1999; Costa and McCrae 1992) and the six-factor model of HEXACO (Ashton and Lee 2009; Lee and Ashton 2018). The most acceptable model is the five-factor model as it includes fewer variables, for example, 32 variables for the five-factor model, instead of 60 or 100 variables for both versions of the six-factor model (HEXACO-60 and HEXACO-100), which need a considerable number of observations, and it becomes difficult to perform such complex models with small samples. In addition, according to Kerr et al. (2017), "the topic of personality/psychological traits of entrepreneurs is of great importance for the study of entrepreneurship in a multitude of contexts" (Kerr et al. 2017, p. 36). 
Following the work of Allport (1937), Cattell (1950), Eysenck (1960), Norman (1963), and Tupes and Christal (1961), many researchers, including Costa and McCrae (1992), worked on developing a scale by which we can measure personality traits. As Clark (2007, p. 246) states: "The five-factor model of personality is widely accepted as representing the higher-order structure of both normal and abnormal personality traits". This is the reason we use this model to connect personality psychology to effectuation theory.

The five-factor theory is an explanatory model that identifies five different bipolar traits among people. It was, as previously mentioned, based on the research of Gordon Allport (1937), Hans Eysenck (1960), and Raymond Cattell (1950). According to Costa and McCrae (1992), these five traits are openness, conscientiousness, extraversion, agreeableness, and neuroticism.

Openness is a term referring to a broader constellation of traits. People who score high on openness are imaginative and sensitive to beauty and art and have a rich and complex emotional life; they are intellectually curious, behaviourally flexible, and non-dogmatic in their values and attitudes.

Conscientiousness is a dimension that contrasts scrupulous, well-organised, and diligent people who are perceived as trustworthy and less impulsive. They are often very goal-oriented and strict in their behavioural patterns.

Extraversion is first mentioned by Carl Jung (1933). The dimension consists of a broad group of traits, including sociability, activity, and a tendency to experience positive emotions such as joy and pleasure. Therefore, this trait should be of the essence when it comes to networking skills and other interpersonal abilities needed as an entrepreneur.

Agreeableness is a primarily descriptive dimension of interpersonal behaviour. People who score high on agreeableness are seen as trusting, sympathetic, and cooperative, whilst people who score low on agreeableness are viewed as callous, cynical, and antagonistic.

The last dimension, neuroticism, is most familiar to clinicians and practitioners of psychology. It represents the individual's tendency to experience psychological distress and discomfort, and a high score regarding neuroticism is typical for most psychiatric conditions.

Kvasova (2015) conducted a study on the relation between eco-friendly behaviour and the big-5 personality traits. She concluded that traits such as openness and extraversion positively impact the entrepreneur's eco-friendliness. Strohhecker and Größler (2013) reached a similar conclusion, in studying the relationship between personality traits and inventory management performance. They concluded that there is a strong relationship between personality traits and performance. This suggests a correlation between traits and the decisions that managers make.

In terms of effectuation as a specific area, there has been only a limited amount of research connecting the theoretical framework with psychology and no research when it comes to making the connection between the DSM5 model and the application of decisionmaking logic.

The question of willingness to take risks is something that should be essential to entrepreneurship as well as to Sarasvathy's (2001) principle of affordable loss. Caliendo et al. (2009) studied the relationship between risk attitudes and entrepreneurship. According to their research, entrepreneurs as a population tend to be less risk-averse than the population in general. However, affordable loss is a concept that other researchers such as Daniel et al. (2015) also extend to apply social capital.

Sarasvathy (2001) argues that entrepreneurs generally tend to opt for effectuation rather than causation. This correlates with the findings of Caliendo et al. (2009), who conclude that to become an entrepreneur, one has to have personality traits that enable the person to handle uncertainty. Part of that strategy is to engage in network building and co-creation, as described by Sarasvathy $(2001,2009)$.

There has so far been a state of disagreement between researchers whose specialisation is business and those whose expertise is the field of psychology. The two groups of researchers have studied leadership but from different vantage points. 
The issue of leadership has long been a debated topic in the social sciences, and researchers such as Bass and Stogdill (1990), Bennis (2007), Derue et al. (2011), and Avolio et al. (2003) have discussed the implications of leadership from a psychological aspect but very seldom has there been a connection between the field of psychology and that of business. Sarasvathy (2001) stated that leaders-or, more narrowly, entrepreneurs-have a set of common traits. That is an assumption partly supported by Derue et al. (2011) and other researchers in the field of psychology. They state that leader traits can be divided into three distinct categories. The first has to do with demographics, the second is related to traits of task competence, and the third is connected with interpersonal attributes.

Derue et al. (2011) also concludes that behaviour, something that is determined to an extent by the traits of the person, is oriented towards (1) task processes, (2) relational dynamics, and (3) change. This is something that is also supported by Avolio et al. (2003), Bass and Bass (2008), and Yukl et al. (2002).

In this respect, Sarasvathy's assumption can be seen as an overly simplified view of leadership and traits. In one respect, her view that entrepreneurs possess a particular set of traits can be traced far back to Carlyle's "grand man" theory, which states that great leaders all have some traits in common (Spector 2016). This view of leadership was early criticised by researchers such as Mann (1959), Jenkins (1947), and Stogdill (1948). Despite this, some research has been performed to investigate whether leaders possess a particular set of traits. Bass and Bass (2008) carried out research about task competence, whilst Bass and Stogdill (1990) asked two questions: (a) which traits distinguish leaders from others, and (b) what is the magnitude of those differences? As of now, almost no research has focused on the magnitude of those differences (Derue et al. 2011). Another source of criticism is from those denying that these traits are static, namely, proponents of the cognitive adaptive trait theory. They argue that traits can be seen as variations in strategies for managing critical adaptive challenges in the interaction with the environment (Matthews 2018; Walter and Yuichi 1995).

The five-factor model was presented as a theoretical advance that has important implications for many areas, including clinical practice. When it comes to management, the link with psychology has, in many ways, been a weak one. By assessing traits from each of the five factors, one can obtain a comprehensive portrait of an individual's personality, something that was highly stressed by Costa and McCrae (1992). We set out to empirically test the relations between causation and effectuation and the entrepreneur and his or her traits with the logic applied.

\subsection{Hypotheses Building and the Conceptual Model}

The authors test the following 25 hypotheses segmented into 5 main sub-groups of hypotheses in the study of the conceptual model:

H.1.6: F1 to F6 and H1.7, H1.8, H1.9 and H.1.10: F1 to F7-F10: Openness is positively and significantly related to causation logic and effectuation logic (experimentation, affordable loss, flexibility, and pre-commitment).

H.2.6: F2 to F6 and H2.7, H2.8, H2.9 and H2.10: F2 to F7-F10: Conscientiousness is positively and significantly related to causation logic and effectuation logic (experimentation, affordable loss, flexibility, and pre-commitment).

H.3.6: F3 to F6 and H3.7, H3.8, H3.9 and H3.10: F3 to F7-F10: Extraversion is positively and significantly related to causation logic and effectuation logic (experimentation, affordable loss, flexibility, and pre-commitment).

H.4.6: F4 to F6 and H4.7, H4.8, H4.9 and H4.10: F4 to F7-F10: Agreeableness is positively and significantly related to causation logic and effectuation logic (experimentation, affordable loss, flexibility, and pre-commitment).

H.5.6: F5 to F6 and H5.7, H5.8, H5.9 and H5.10: F5 to F7-F10: Neuroticism is positively and significantly related to causation logic and effectuation logic (experimentation, affordable loss, flexibility, and pre-commitment). 
Figure 1 below indicates the conceptual model of the study. The model shows that the manager's personality traits, together with his/her knowledge and prior experience, affect the choice of decision-making model he/she will adopt. The adoption of the decisionmaking model will later determine the growth of the firm.

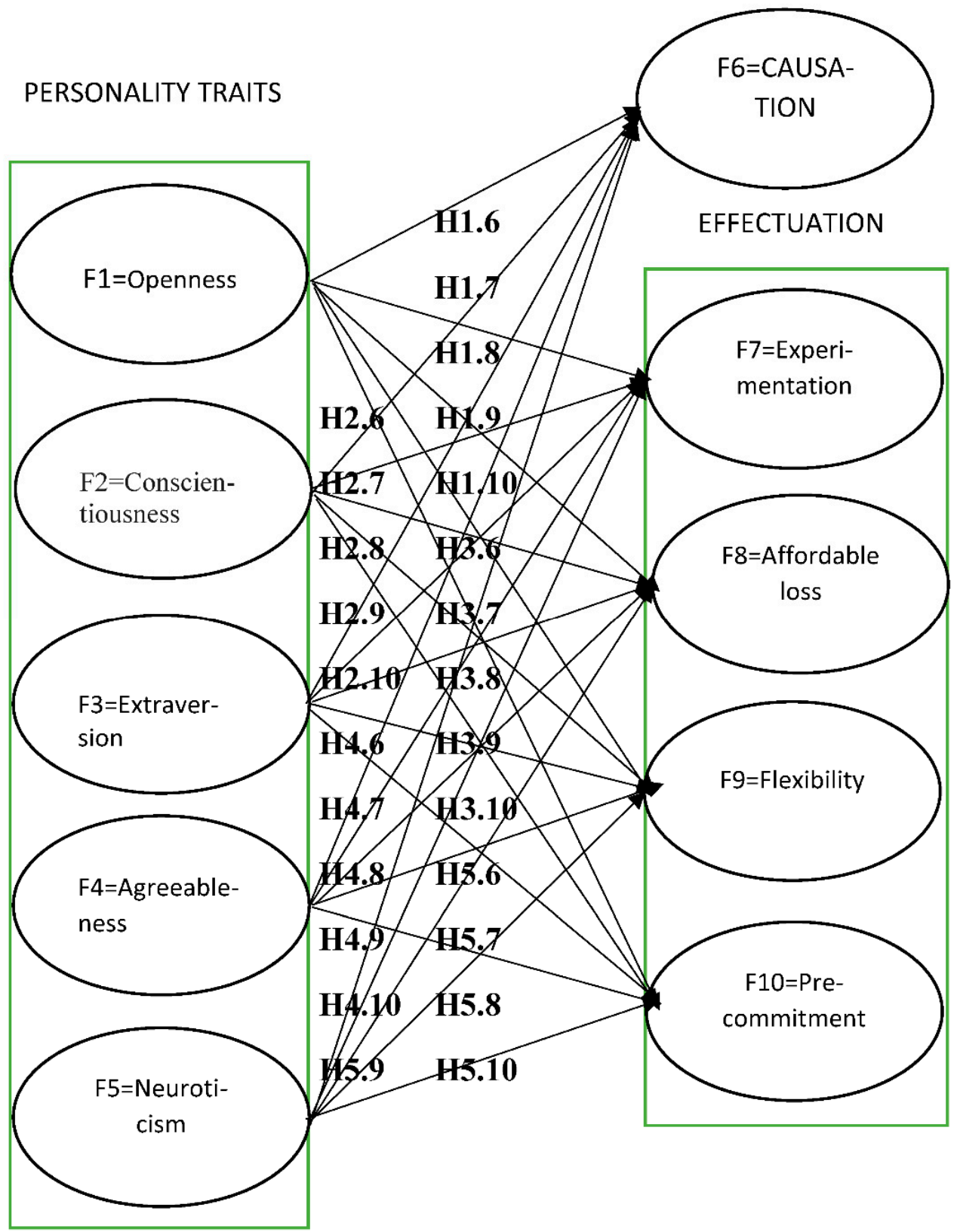

Figure 1. The conceptual model. Positive and significant relationships: F4 to F7: 0.938, F2 to F8: 0.872, F1 to F9: 0.814 , F1 to F7: 0.756, F3 to F7: 0.735, F4 to F9: 0.723, F2 to F10: 0.705, F3 to F9: 0.571, and F2 to F6: 0.560 .

Since most researchers agree that personality traits are for the most part inherited, the question also arises as to whether a person's traits are something that can be changed or whether a person throughout their life is set by a certain number of traits, that, in one respect, reduces the importance of the experience or knowledge factor. Sometimes humans interpret and process information in a way that is in congruence with their personality. A person who scores low on openness might not be interested or able to open for new information. The same goes for agreeableness and the other factors. They all set the boundaries for what we can experience and learn. Researchers such as Mas-Colell et al. 
(1995) examined psychological variables as restraining factors. These are issues that Sarasvathy and most other scientists have not considered, perhaps because all, or nearly all, the research into effectuation has so far been conducted by economists and not by people with specialist knowledge in psychology.

\title{
3. Methodology
}

\subsection{Operationalisation of the Study}

Table 1 below shows the operationalisation of the three constructs used in the conceptual model in Figure 1, i.e., personality traits, causation, and effectuation.

Table 1. Operationalisation of personality traits and causation and effectuation *.

Operationalisation of personality traits adapted from McCrae and Costa (1987)

\section{Openness}

When I encounter a new technology or phenomena, I feel positive towards trying it out.

I often have innovative ideas that I am curious about when trying to turn to a venture.

I like adventure and to look at beautiful things.

I have a wide range of interests in different fields.

I feel excited when I encounter new things, experiences, or ideas.

I would say my values are in congruence with the society in which I live.

I regard myself as a competent person and I take pride in it.

When I start something, I tend to follow through to the end.

I am a goal-oriented person.

People often tell me that I am an efficient person and it is something I take pride in. I regard myself as an efficient person.

I like things to be in order and I dislike disorder.

I am a disciplined person and laziness is something I dislike in myself and/or in others.

I am an impulsive person.

\section{Extraversion}

I am full of energy.

To be and feel excitement is of great importance to me.

In general, my emotions are positive, and I feel enthusiastic.

I am an outgoing person.

I am an assertive/forceful person.

To be around other people is something I really like.

\section{Agreeableness}

I am a compassionate person who tries to understand the needs and wishes of others.

I trust other people.

I forgive people easily.

I tell people straightforward what I think.

I am a warm person.

I comply with instructions.

I am modest as a person and I tend not to "Show off".

\author{
Neuroticism \\ I often feel vulnerable. \\ I often feel anxious. \\ I often feel depressed.
}

I often feel anger towards myself or others.

I regard myself as a shy person.

I often feel moody and impulsive. 
Table 1. Cont.

Operationalisation of causation and effectuation adapted from Chandler et al. (2011)
CAUSATION
Causation
return.
While starting up my current business, I analysed long-term opportunities and selected what I thought would provide the best
While starting up my current business, I developed a strategy to best take advantage of resources and capabilities.
While starting up my current business, I designed and planned business strategies.
While starting up my current business, I organised and implemented control processes to make sure I met objectives, e.g.,
establishing an internal reporting structure in a fixed time such as monthly or biannual reports.
While starting up my current business, I researched and selected target markets and did meaningful competitive analysis.
While starting up my current business, I had a clear and consistent vision of where I wanted to end up.
While starting up my current business, I designed and planned tour operating services and marketing efforts.
EFFECTUATION
Experimentation
The service that I now provide is essentially the same as originally conceptualised.
The service that I now provide is substantially different than I first imagined.
packages I use now have been developed after many trial and error efforts.

\section{Affordable Loss}

While starting up my current business, I was careful not to commit more resources than I could afford to lose.

While starting up my current business, I was careful not to risk more money than I was willing to lose with my initial idea. While starting up my current business, I was careful not to risk so much money that my firm would be in real trouble financially if things did not work out.

Flexibility
When I started my current business, I allowed the business to evolve as opportunities emerged.
While starting up my current business, I was flexible and took advantage of opportunities as they arose, e.g., instead of following a
rigid business plan, having a business plan that changes situationally.
While starting up my current business, I avoided courses of action that restricted my flexibility and adaptability.

\section{Pre-commitment}

While starting up my current business, I used pre-commitments from clients as often as possible, e.g., asking for a down payment. While starting up my current business, I signed several agreements with my clients and suppliers in order to reduce the risk factor.

Note *: The measurement of the above items is based on 7-point Likert scales from fully disagree $=1$ point to fully agree $=7$ points.

The questionnaire used in this study is adapted from researchers of the respective fields. For example, the study by Costa and McCrae (1992) is used for the items of personality traits, and the study by Chandler et al. (2011) regarding the items of causation and effectuation.

There is evidence that different personality traits make different types of behaviour more or less likely. Costa and McCrae (1992), and McCrae and Costa (1999) identified and described these personality traits and the likely behaviour associated with them. Sarasvathy (2001) laid out a theory that described two sets of decision-making logics, namely, effectuation and causation. The current study aims to connect personality traits of psychology and effectuation theory and entrepreneurial process theory. There is always a risk of empirical studies being based on an unpopular conceptual model, but in this research, the risk of errors is low since it builds upon two mature and widely accepted theoretical frameworks and the theory of entrepreneurial process, which is still under development (Trabskaia and Mets 2021).

This research is built upon previous research by Sarasvathy $(2001,2009)$ as well as McCrae and Costa $(1987,1999)$ and Costa and McCrae (1992), and the theories they represent are mature in their nature. The theory of effectuation has matured, during recent years, whilst the five-factor theory of personality traits is a generally accepted theory (Matalamäki 2017; Cervone and Pervin 2013). 


\subsection{The Sample}

The population of the Estonian IT companies was drawn from three online sources of company databases: (a) The Estonian Startup Database (2021), which included 1216 companies. The study used only 639 companies from this database, as follows: 224 companies from Business Software and HR, 159 companies from FinTech, 103 companies from AdTech and Creative Tech, 52 companies from Communication, 48 companies from TravelTech, 42 companies from EdTech, and 11 companies from SpaceTech; (b) The Top Software Development Companies in Estonia (2021), which included 50 companies; (c) The Top 50 IT Services Companies in Estonia (2021), which included 47 companies. In total, 736 companies were considered for the population of Estonian IT companies in the above three databases, of which 4 were duplicates in the databases. Therefore, the population of the Estonian IT companies totalled 732.

\section{Findings}

\subsection{The Profile of Participants}

The study was based on the Estonian IT sector and 115 fully completed surveys were received through the platform connect.ee. This research platform is an online one in which researchers can develop their surveys and invite participants to complete these surveys. This platform also provides the researcher with an Excel file for the gathering of final data without spending the researcher's time in developing such a file for the needs of quantitative analyses.

The profile of participants in the survey is as follows: 65 males and 50 females replied to the questionnaire with an average age of 37.2 years. Furthermore, 83 participants (72.2\%) were located in Tallinn. Regarding education level, 40 participants (34.8\%) had a master's degree, $39(33.9 \%)$ a bachelor's degree, and $17(14.8 \%)$ a higher than master's degree. In terms of occupation, most participants, $102(88.7 \%)$, were entrepreneurs/managers in IT companies and $13(11.3 \%)$ assistant managers/team members of IT project management/IT electronics. Regarding nationality, 51 participants (44.3\%) were Estonians, 11 (9.6\%) Russians, and $53(46.1 \%)$ other nationalities. In terms of experience in years, the participants replied as follows: $1-5$ years: 46 (39.9\%), 6-10 years: 26 (22.5\%), 11-20 years: $23(19.9 \%)$, 21-30 years: $10(6.7 \%)$, and 31-40 years: 7 (6.1\%). Regarding whether this is their first business, the participants replied as follows: yes: $73(63.6 \%)$ and no: $42(36.4 \%)$.

Managers/entrepreneurs of IT companies in Estonia were invited to complete the online questionnaire on this platform. Two reminders were sent to prospective participants of the IT sector in Estonia. There was also a telephone call to remind the managers to complete the online questionnaire. The collection of surveys lasted for seven months from January to July 2020. Two of the received surveys were eliminated from the sample as negative outliers, where the total score given by the participants to their replies to the 51 items of the conceptual model were very low, i.e., 88 and 91 points, respectively. The score of each item varied from 1 to 7 points and the total scores of the 51 items of the conceptual model, as shown in Figure 1 above, were in the range of 88 to 197 points, with most of the replies scoring between 120 to 180 points.

\subsection{Confirmatory Factor Analysis}

Confirmatory factor analysis (CFA) was used to test the fit of the model. This was satisfactory as both statistics of RMSEA and CFI were 0.094 and 0.735 , respectively, as provided by the small sample of 113 surveys (Hair et al. 2014). There were no missing values of any variables The initial non-unidimensional solution of AMOS 27 found a chi-square $=2461.1$ with $\mathrm{df}=1179, \mathrm{CFI}=0.678$ and RMSEA $=0.099$. The unidimensional solution was achieved in the 13 th run of the model with chi-square $=2588.1, \mathrm{CFI}=0.650$, and RMSEA $=0.102$. The CFA in the process used the maximum likelihood tool with bootstrap 2000 times. The modification indices revealed e 18 to e $19=57.860$, e 28 to e $29=10.753$, e7 to $\mathrm{e} 8=10.296$, e21 to e $22=9.581$, e 36 to e37 $=8.287$, e20 to e22 $=8.155$, e21 to e23 $=7.174$, and e 39 to $\mathrm{e} 41=6.081$, e 13 to $\mathrm{e} 17=5.447$, e 9 to $\mathrm{e} 12=4.190$, and $\mathrm{e} 43$ to e $45=4.018$. The 
11th covariance of e43 to e45 produced an estimate with chi-square $=2429.3, \mathrm{df}=1180$, $\mathrm{CMIN} / \mathrm{DF}=2.059, \mathrm{CFI}=0.687$, and RMSEA $=0.097$.

Since the 19th case produced Mahalanobis d-squared $=91.723$, we had to eliminate this case as this value was extremely high, namely, above 80,000 , but it produced a worse RMSEA $=0.099$ and CFI $=0.681$ than the solution of the 11th covariances. Furthermore, eight of the variables generated standardised regression weights below the acceptable value of 0.500 , but only four variables were eliminated, i.e., F4: A7, F1: O6, F4: A4, and F3: E1. In particular, each elimination of the four variables produced the following fit of the model:

(a) The extraction from construct F4 of the variable A7: chi-square $=2323.4, \mathrm{df}=1131$, $\mathrm{CMIN} / \mathrm{DF}=2.054, \mathrm{CFI}=0.697$, and RMSEA $=0.097$.

(b) The elimination from construct $\mathrm{F} 1$ of the variable O6: from construct $\mathrm{F} 1$ the researchers extract the variable O6: chi-square $=2235.2, \mathrm{df}=1084, \mathrm{CMIN} / \mathrm{DF}=2.062, \mathrm{CFI}=0.704$, and RMSEA $=0.097$.

(c) The extraction from construct F4 of the variable A4: chi-square $=2137.4, \mathrm{df}=1038$, $\mathrm{CMIN} / \mathrm{DF}=2.059, \mathrm{CFI}=0.712$, and $\mathrm{RMSEA}=0.097$.

(d) The elimination from construct F3 of the variable E1: chi-square $=1982.0, \mathrm{df}=992$, $\mathrm{CMIN} / \mathrm{DF}=1.998, \mathrm{CFI}=0.735$, and RMSEA $=0.094$.

Therefore, the elimination of the above four variables produced an estimate with chi-square $=1982.0, \mathrm{df}=992, \mathrm{CMIN} / \mathrm{DF}=1.998, \mathrm{CFI}=0.735$, and $\mathrm{RMSEA}=0.094$.

Furthermore, the researchers extracted a total of eight variables, which had standardized regression weights below the threshold of 0.5. However, the estimation of the final model was worse in terms of RMSEA $=0.095$. The extraction of all eight variables from the model produced the following estimations of the model:

(a) Extraction from construct F4 the variable A7: chi-square $=2323.4, \mathrm{df}=1131, \mathrm{CMIN} / \mathrm{DF}$ $=2.054, \mathrm{CFI}=0.697$, and RMSEA $=0.097$.

(b) From construct F1 the researchers extracted the variable O6: chi-square $=2235.2, \mathrm{df}=$ $1084, \mathrm{CMIN} / \mathrm{DF}=2.062, \mathrm{CFI}=0.704$, and $\mathrm{RMSEA}=0.097$.

(c) From construct F4 the variable A4 was extracted: chi-square $=2137.4, \mathrm{df}=1038$, $\mathrm{CMIN} / \mathrm{DF}=2.059, \mathrm{CFI}=0.712$, and $\mathrm{RMSEA}=0.097$.

(d) From construct F4 the researchers extracted the variable A5: chi-square $=2054.2, \mathrm{df}=$ 992, $\mathrm{CMIN} / \mathrm{DF}=2.071, \mathrm{CFI}=0.719$, and RMSEA $=0.098$.

(e) Extracted from construct F2 was the variable CAU2: chi-square $=1974.4, \mathrm{df}=947$, $\mathrm{CMIN} / \mathrm{DF}=2.085, \mathrm{CFI}=0.724$, and $\mathrm{RMSEA}=0.098$.

(f) From construct F4 the researchers extract the variable A3: chi-square $=1890.4, \mathrm{df}=$ 903, $\mathrm{CMIN} / \mathrm{DF}=2.093, \mathrm{CFI}=0.731$, and $\mathrm{RMSEA}=0.099$.

(g) From construct F4 the variable A6 is extracted: chi-square $=1793.1, \mathrm{df}=860, \mathrm{CMIN} / \mathrm{DF}$ $=2.085, \mathrm{CFI}=0.741$, and RMSEA $=0.098$, and

(h) Extracted from construct F3 was the variable E1: chi-square $=1640.5, \mathrm{df}=818$, $\mathrm{CMIN} / \mathrm{DF}=2.005, \mathrm{CFI}=0.766$, and RMSEA $=0.095$.

The final run of the CFA without the four variables (F4: A7, F1: O6, F4: A4, and F3: E1) produced an estimate $/$ solution with chi-square $=1982.0, \mathrm{CFI}=0.735$, and RMSEA $=0.094$, which is a better estimate compared to the one with the extractions of eight variables. Some statistics of interest found in the test of the fit of the final model without the four variables are as follows: $\mathrm{NPAR}=183, \mathrm{CMIN}=1982.0, \mathrm{DF}=992, \mathrm{P}=0.000, \mathrm{CMIN} / \mathrm{DF}=1.998$, NFI or Delta $1=0.589$, RFI or rho1 $=0.552$, IFI or Delta $2=0.741$, TLI or rho2 $=0.711$, RMSEA $=0.094$, RMSEA LO $90=0.088$, RMSEA HI $90=0.100$, and PCLOSE $=0.000$.

Table 2 below shows the correlation matrix indicating that the correlations are below the threshold value of 0.7 , and therefore, there is no multicollinearity problem. 
Table 2. Correlation matrix $(\mathrm{N}=113)$ *

\begin{tabular}{cllllllllll}
\hline & F1 & F2 & F3 & F4 & F5 & F6 & F7 & F8 & F9 & F10 \\
\hline F1 & $\mathbf{0 . 8 7 3}$ & & & & & & & & & \\
F2 & 0.332 & $\mathbf{0 . 8 5 1}$ & & & & & & & & \\
F3 & 0.711 & 0.497 & $\mathbf{0 . 8 4 4}$ & & & & & & & \\
F4 & 0.644 & 0.368 & 0.685 & $\mathbf{0 . 7 4 0}$ & & & & & & \\
F5 & -0.334 & -0.439 & -0.534 & -0.368 & $\mathbf{0 . 8 4 5}$ & & & & & \\
F6 & -0.300 & 0.335 & -0.163 & -0.200 & 0.064 & $\mathbf{0 . 8 0 8}$ & & & & \\
F7 & 0.326 & 0.048 & 0.373 & 0.386 & -0.193 & -0.480 & $\mathbf{0 . 9 1 6}$ & & & \\
F8 & -0.022 & 0.478 & 0.140 & 0.210 & 0.091 & 0.508 & -0.144 & $\mathbf{0 . 9 2 0}$ & & \\
F9 & 0.428 & -0.106 & 0.352 & 0.363 & -0.128 & -0.787 & 0.655 & -0.416 & $\mathbf{0 . 9 3 9}$ & \\
F10 & -0.167 & 0.379 & -0.064 & -0.033 & -0.058 & 0.426 & -0.036 & 0.565 & -0.416 & $\mathbf{0 . 9 1 2}$ \\
\hline
\end{tabular}

* F1: Openness, F2: Conscientiousness, F3: Extraversion, F4: Agreeableness, F5: Neuroticism, F6: Causation, F7: Experimentation, F8: Affordable loss, F9: Flexibility, and F10: Pre-commitment. Values in diagonal show the square root of AVE.

Figure 2 below shows the final estimate of the model without the four variables already mentioned above.

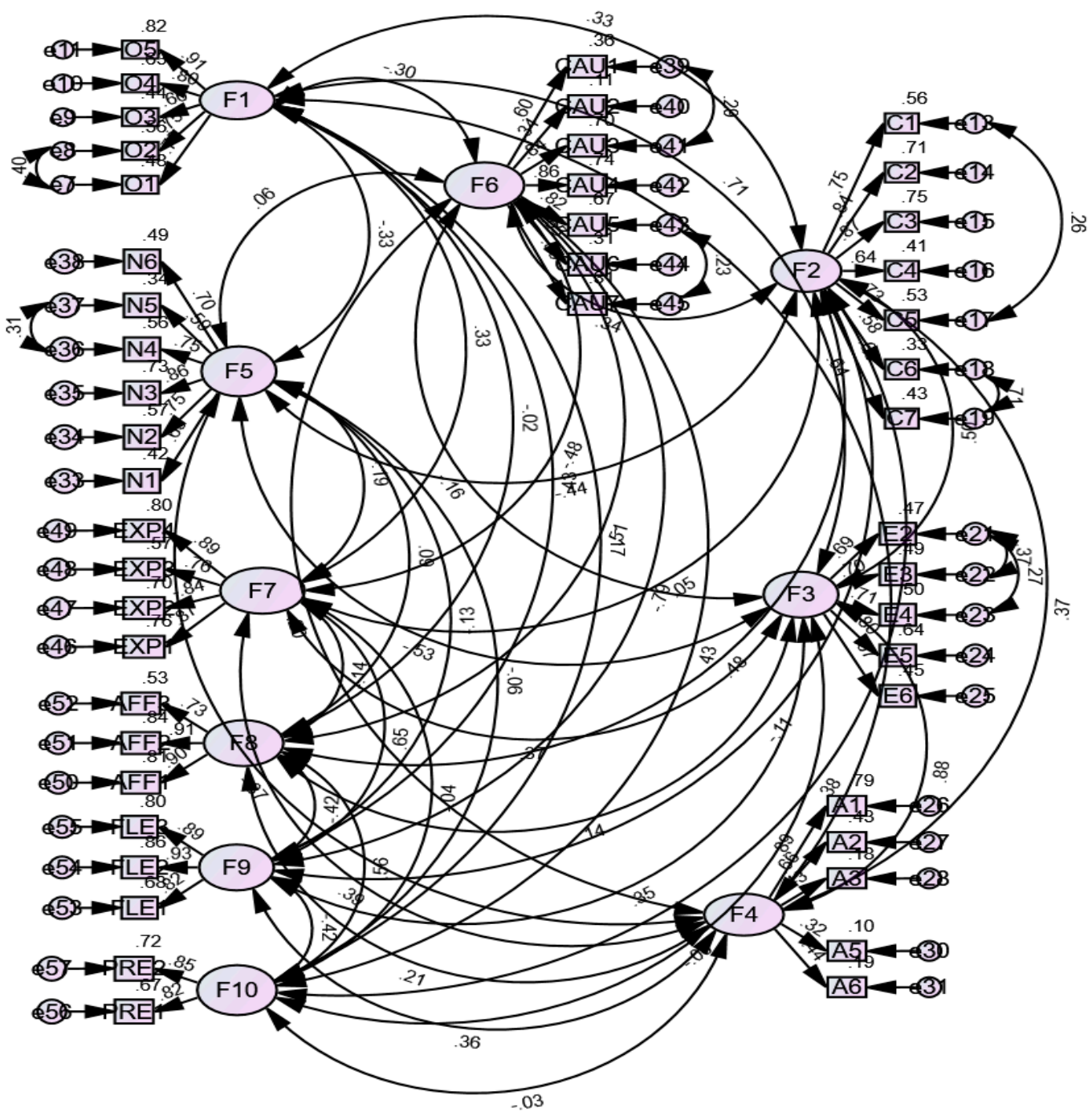

Figure 2. Final estimation of the model with the extraction of four variables.

\subsection{Test of Hypotheses}

Based on the covariances found via CFA of AMOS 27, the study tests the hypotheses as shown in Table 3 below. The covariances were performed between the independent 
constructs F1, F2, F3, F4, F5, and the dependent construct F6 (see Figure 1) and between the independent constructs F1, F2, F3, F4, F5, and the dependent constructs F7, F8, F9, and F10 (see Figure 1 above).

Table 3. Test of hypotheses using CFA (covariances) via AMOS $27(\mathrm{~N}=113)$.

\begin{tabular}{|c|c|c|c|c|c|c|}
\hline \multirow{2}{*}{ Hypotheses } & \multirow{2}{*}{ Relationship * } & \multicolumn{2}{|c|}{ Estimate } & \multirow{2}{*}{ C.R. (t) } & \multirow{2}{*}{ Sig. ( $p$-Value) } & \multirow{2}{*}{$\begin{array}{c}\text { Status of } \\
\text { Hypotheses }\end{array}$} \\
\hline & & Beta & Std. Error & & & \\
\hline H1.6 & F1: Openness to F6 & -0.577 & 0.215 & -2.681 & 0.007 & Non-supported \\
\hline H2.6 & F2: Conscientiousness to F6 & 0.560 & 0.187 & 2.999 & 0.003 & Supported \\
\hline H3.6 & F3: Extraversion to F6 & -0.267 & 0.188 & -1.418 & 0.156 & Non-supported \\
\hline H4.6 & F4: Agreeableness to F6 & -0.404 & 0.231 & -1.753 & 0.080 & Non-supported \\
\hline H5.6 & F5: Neuroticism to F6 & 0.127 & 0.213 & 0.593 & 0.553 & Non-supported \\
\hline H1.7 & F1: Openness to F7 & 0.756 & 0.256 & 2.956 & 0.003 & Supported \\
\hline $\mathrm{H} 2.7$ & F2: Conscientiousness to F7 & 0.097 & 0.211 & 0.458 & 0.647 & Non-supported \\
\hline H3.7 & F3: Extraversion to F7 & 0.735 & 0.230 & 3.194 & 0.001 & Supported \\
\hline H4.7 & F4: Agreeableness to F7 & 0.938 & 0.283 & 3.317 & 0.000 & Supported \\
\hline H5.7 & F5: Neuroticism to F7 & -0.456 & 0.255 & -1.789 & 0.074 & Non-supported \\
\hline H1.8 & F1: Openness to F8 & -0.047 & 0.220 & -0.214 & 0.831 & Non-supported \\
\hline H2.8 & F2: Conscientiousness to F8 & 0.872 & 0.212 & 4.108 & 0.000 & Supported \\
\hline H3.8 & F3: Extraversion to F8 & 0.251 & 0.199 & 1.262 & 0.207 & Non-supported \\
\hline $\mathrm{H} 4.8$ & F4: Agreeableness to F8 & 0.462 & 0.244 & 1.892 & 0.058 & Non-supported \\
\hline H5.8 & F5: Neuroticism to F8 & 0.195 & 0.230 & 0.851 & 0.395 & Non-supported \\
\hline H1.9 & F1: Openness to F9 & 0.814 & 0.213 & 3.819 & 0.000 & Supported \\
\hline H2.9 & F2: Conscientiousness to F9 & -0.176 & 0.175 & -1.004 & 0.315 & Non-supported \\
\hline H3.9 & F3: Extraversion to F9 & 0.571 & 0.186 & 3.070 & 0.002 & Supported \\
\hline H4.9 & F4: Agreeableness to F9 & 0.723 & 0.227 & 3.188 & 0.001 & Supported \\
\hline H5.9 & F5: Neuroticism to F9 & -0.249 & 0.206 & -1.210 & 0.226 & Non-supported \\
\hline H1.10 & F1: Openness to F10 & -0.358 & 0.239 & -1.496 & 0.135 & Non-supported \\
\hline H2.10 & F2: Conscientiousness to F10 & 0.705 & 0.234 & 3.010 & 0.003 & Supported \\
\hline H3.10 & F3: Extraversion to F10 & -0.116 & 0.213 & -0.543 & 0.587 & Non-supported \\
\hline H4.10 & F4: Agreeableness to F10 & -0.074 & 0.260 & -0.285 & 0.775 & Non-supported \\
\hline H5.10 & F5: Neuroticism to F10 & -0.128 & 0.283 & -0.451 & 0.652 & Non-supported \\
\hline
\end{tabular}

* F6: Causation, F7: Experimentation, F8: Affordable Loss, F9: Flexibility, and F10: Pre-commitment.

Table 3 shows that nine from the total 25 hypotheses, namely, H2.6, H1.7, H3.7, H4.7, $\mathrm{H} 2.8, \mathrm{H} 1.9, \mathrm{H} 3.9, \mathrm{H} 4.9$, and $\mathrm{H} 2.10$ are supported, and these relationships of the model are positive and significant at the $99 \%$ confidence level.

Table 3 shows that the most impactful relationships are as follows: agreeableness to experimentation (F4 to F7: 0.938), conscientiousness to affordable loss (F2 to F8: 0.872), openness to flexibility (F1 to F9: 0.814), openness to experimentation (F1 to F7: 0.756), extraversion to experimentation (F3 to F7: 0.735), agreeableness to flexibility (F4 to F9: 0.723), and conscientiousness to pre-commitment (F2 to F10: 0.705). The remaining two relationships have both lower effects, i.e., extraversion to flexibility (F3 to F9: 0.571) and conscientiousness to causation (F2 to F6: 0.560).

\subsection{Reliability and Validity}

This study measures reliability via the construct reliabilities calculated in Table 4 with the use of CFA and the estimation of Cronbach's $\alpha$ of the eight constructs. Table 4 reveals that all constructs have construct reliabilities above 0.7 and the average construct reliability is 0.907 . Additionally, the calculated construct reliabilities via CFA of Table 4 are specifically the following: F1: Openness $=0.924$, F2: Conscientiousness $=0.930$, F3: Extraversion $=0.898$, F4: Agreeableness $=0.814$, F5: Neuroticism $=0.883$, F6: Causation $=0.896$, F7: Experimentation $=0.946$, F8: Affordable loss $=0.934$, F9: Flexibility $=0.952$, and F10: Precommitment $=0.891$. 
Table 4. Completely standardised factor loadings, variance extracted, and estimates of construct reliability $(\mathrm{N}=113)$ *

\begin{tabular}{|c|c|c|c|c|c|c|c|c|c|c|c|c|c|}
\hline \multirow{2}{*}{ Variables } & \multicolumn{11}{|c|}{ Item Reliability } & \multirow{2}{*}{$\begin{array}{l}\text { Eigen- } \\
\text { Values }\end{array}$} & \multirow{2}{*}{$\begin{array}{c}\delta=1 \text {-Item } \\
\text { Reliability }\end{array}$} \\
\hline & F1 & F2 & F3 & F4 & F5 & F6 & F7 & F8 & F9 & F10 & & & \\
\hline O1 & 0.696 & & & & & & & & & & 0.696 & & 0.304 \\
\hline $\mathrm{O} 2$ & 0.748 & & & & & & & & & & 0.748 & & 0.252 \\
\hline $\mathrm{O} 3$ & 0.661 & & & & & & & & & & 0.661 & & 0.339 \\
\hline $\mathrm{O} 4$ & 0.796 & & & & & & & & & & 0.796 & & 0.204 \\
\hline O5 & 0.906 & & & & & & & & & & 0.906 & 3.807 & 0.094 \\
\hline $\mathrm{C} 1$ & & 0.751 & & & & & & & & & 0.751 & & 0.249 \\
\hline $\mathrm{C} 2$ & & 0.843 & & & & & & & & & 0.843 & & 0.157 \\
\hline $\mathrm{C} 3$ & & 0.869 & & & & & & & & & 0.869 & & 0.131 \\
\hline $\mathrm{C} 4$ & & 0.643 & & & & & & & & & 0.643 & & 0.357 \\
\hline $\mathrm{C} 5$ & & 0.729 & & & & & & & & & 0.729 & & 0.271 \\
\hline C6 & & 0.576 & & & & & & & & & 0.576 & & 0.424 \\
\hline $\mathrm{C} 7$ & & 0.659 & & & & & & & & & 0.659 & 5.07 & 0.341 \\
\hline E2 & & & 0.686 & & & & & & & & 0.686 & & 0.314 \\
\hline E3 & & & 0.697 & & & & & & & & 0.697 & & 0.303 \\
\hline $\mathrm{E} 4$ & & & 0.709 & & & & & & & & 0.709 & & 0.291 \\
\hline E5 & & & 0.800 & & & & & & & & 0.800 & & 0.200 \\
\hline E6 & & & 0.671 & & & & & & & & 0.671 & 3.563 & 0.329 \\
\hline A1 & & & & 0.890 & & & & & & & 0.890 & & 0.110 \\
\hline $\mathrm{A} 2$ & & & & 0.657 & & & & & & & 0.657 & & 0.343 \\
\hline $\mathrm{A} 3$ & & & & 0.427 & & & & & & & 0.427 & & 0.573 \\
\hline A5 & & & & 0.322 & & & & & & & 0.322 & & 0.678 \\
\hline A6 & & & & 0.441 & & & & & & & 0.441 & 2.737 & 0.559 \\
\hline N1 & & & & & 0.648 & & & & & & 0.648 & & 0.352 \\
\hline N2 & & & & & 0.752 & & & & & & 0.752 & & 0.248 \\
\hline N3 & & & & & 0.856 & & & & & & 0.856 & & 0.144 \\
\hline N4 & & & & & 0.746 & & & & & & 0.746 & & 0.254 \\
\hline N5 & & & & & 0.585 & & & & & & 0.585 & & 0.415 \\
\hline N6 & & & & & 0.698 & & & & & & 0.698 & 4.285 & 0.302 \\
\hline CAU1 & & & & & & 0.603 & & & & & 0.603 & & 0.397 \\
\hline CAU2 & & & & & & 0.336 & & & & & 0.336 & & 0.664 \\
\hline CAU3 & & & & & & 0.839 & & & & & 0.839 & & 0.161 \\
\hline CAU4 & & & & & & 0.862 & & & & & 0.862 & & 0.138 \\
\hline CAU5 & & & & & & 0.821 & & & & & 0.821 & & 0.179 \\
\hline CAU6 & & & & & & 0.554 & & & & & 0.554 & & 0.446 \\
\hline CAU7 & & & & & & 0.554 & & & & & 0.554 & 4.569 & 0.446 \\
\hline EXP1 & & & & & & & 0.869 & & & & 0.869 & & 0.131 \\
\hline EXP2 & & & & & & & 0.836 & & & & 0.836 & & 0.164 \\
\hline EXP3 & & & & & & & 0.755 & & & & 0.755 & & 0.245 \\
\hline EXP4 & & & & & & & 0.894 & & & & 0.894 & 3.354 & 0.106 \\
\hline AFF1 & & & & & & & & 0.898 & & & 0.898 & & 0.102 \\
\hline AFF2 & & & & & & & & 0.915 & & & 0.915 & & 0.085 \\
\hline AFF3 & & & & & & & & 0.728 & & & 0.728 & 2.541 & 0.272 \\
\hline FLE1 & & & & & & & & & 0.823 & & 0.823 & & 0.177 \\
\hline FLE2 & & & & & & & & & 0.928 & & 0.928 & & 0.072 \\
\hline FLE3 & & & & & & & & & 0.894 & & 0.894 & 2.645 & 0.106 \\
\hline PRE1 & & & & & & & & & & 0.817 & 0.817 & & 0.183 \\
\hline PRE2 & & & & & & & & & & 0.846 & 0.846 & 1.663 & 0.154 \\
\hline $\begin{array}{c}\text { Variance } \\
\text { Extracted \% }\end{array}$ & 76.14 & 72.43 & 71.26 & 54.74 & 71.42 & 65.27 & 83.85 & 84.70 & 88.17 & 83.15 & $\mathrm{AVE}=75.11$ & & \\
\hline $\begin{array}{l}\text { Construct } \\
\text { Reliability }\end{array}$ & 0.924 & 0.930 & 0.898 & 0.814 & 0.883 & 0.896 & 0.946 & 0.934 & 0.952 & 0.891 & $\mathrm{ACR}=0.907$ & & \\
\hline
\end{tabular}

* Note: The following formulae are used for calculating VE and CR of constructs: VE $=\Sigma$ of standardised regression weights $/ n, C R=(\Sigma$ of standardised regression weights $)^{2} /\left[(\Sigma \text { of standardised regression weights })^{2}+(\Sigma \delta)\right]$, AVE $=$ average variance extracted, ACR $=$ average construct reliability. Constructs: F1: Openness, F2: Conscientiousness, F3: Extraversion, F4: Agreeableness, F5: Neuroticism, F6: Causation, F7: Experimentation, F8: Affordable loss, F9: Flexibility, and F10: Pre-commitment. 
Furthermore, Cronbach's $\alpha$ of the ten constructs are above the critical value of 0.7. In particular, Cronbach's $\alpha$ are calculated via Scale Tool Reliability Analysis in SPSS 27 as follows: F1: Openness $=0.843$, F2: Conscientiousness $=0.862$, F3: Extraversion $=0.841$, F4: Agreeableness = 0.665, F5: Neuroticism =0.844, F6: Causation = 0.825, F7: Experimentation $=0.666$, F8: Affordable loss $=0.874$, F9: Flexibility $=0.899$, and F10: Pre-commitment $=0.817$ The average Cronbach's $\alpha$ is 0.814 .

The study performs a two-step procedure to evaluate convergent validity. Firstly, the standardised regression weights of all variables are above 0.5 (except for four values). The range of the standardised regression weights is between 0.322 to 0.928 , showing no convergent validity. Since only 25 out of 47 values of standardised regression weights are above 0.7 , this provides evidence that there is no convergent validity. Secondly, the calculation of the variance extracted from each construct exceeded 50\%, and consequently, the model showed some convergent validity. Specifically, the variance extracted for the ten constructs was above 50\% (F1: Openness $=0.761, \mathrm{~F} 2$ : Conscientiousness = 0.724, F3: Extraversion $=0.713$, F4: Agreeableness $=0.547$, F5: Neuroticism $=0.714$, F6: Causation $=0.653$, F7: Experimentation $=0.839$, F8: Affordable loss $=0.847$, F9: Flexibility $=0.882$, and F10: Pre-commitment $=0.832$ ), and the average variance extracted (AVE) was 0.751 . These calculations reveal that each construct has a variance extracted greater than 0.5. Since the AVE is 0.751, greater than 0.5, the Fornell and Larcker's (1981) discriminantvalidity criterion is satisfied, meaning that the average variance extracted is greater than 0.5 for each construct. Table 2 above shows the criteria for discriminant validity, which is established when the square root of AVE is higher than the correlation among the constructs. All the constructs explain more information through their items than through their inter-relationships. Based on Hu and Bentler (1999), all the constructs performed well, suggesting that they can be used to investigate the conceptual model (see Figure 1).

\section{Discussion}

Recently, there have been studies in different Eastern European countries on entrepreneurship as follows: Gawel and Głodowska (2021), who investigated the effect of economic dynamics on female entrepreneurship in the Visegrad countries, specifically Czechia, Hungary, Poland, and Slovakia. The study revealed that economic dynamics impact female entrepreneurship to an extent, but in a less important way. This impact is more evident in the trend perspective than in the business cycle perspective. Another study by Trabskaia and Mets (2021) in Estonia investigated the entrepreneurial idea and opportunity within the stages of the entrepreneurial process of seven doctoral students studying an entrepreneurship course. After each lesson and homework, the students assessed the feasibility and attractiveness of their idea and opportunity. The results showed fluctuations in these perception variables depending on the stage of the entrepreneurial process. Furthermore, a study performed in Finland by Joensuu-Salo et al. (2021) investigated the impact of entrepreneurship competence on the antecedent factors of takeover intentions. The study revealed that the subjective norm had a significant effect on takeover intentions, but the effect of entrepreneurship competence was mediated by attitudes and perceived behavioural control.

Furthermore, in addition to the psychological theories of entrepreneurship, which focused on personal characteristics that defined entrepreneurs' behaviours, other research has stressed the link between psychoanalytic thinking and managerial literature, with reference to organisational theory, organisational behaviour, and entrepreneurship aspects. The psychoanalytic approach provided academics with the means to associate unconscious, interpersonal, and intrapsychic processes with corporate aspects and organisational developments.

Regarding the three objectives of the study, the authors to a large extent were satisfied as all three objectives were achieved. In particular, the first objective of the study was satisfied since the five-factor model of personality traits was proved to be a satisfactory one as it predicted both causation logic and effectuation logic. However, in future studies, 
researchers should consider using Kerr et al.'s (2017, p. 25) personality traits or any version of the two six-factor model of personality traits of HEXACO (Ashton and Lee 2009; Lee and Ashton 2018), depending always on the available observations. The second objective was satisfied in that the entrepreneur in a new venture should link the effect of his/her personality traits on the two decision-making logics and, in future, relate decision-making logics with the entrepreneurial process, entrepreneurial intentions, or entrepreneurship competence. The third objective was also satisfied as the study reveals some future research avenues in this topic (see Section 6.4 on future research below).

\section{Conclusions, Theoretical and Managerial Implications, Limitations, and Future Research}

\subsection{Conclusions}

This study, which is based on a sample of 113 managers/entrepreneurs working in the Estonian IT sector, reveals that the fit of the model is satisfactory with chi-square $=1982.0$, $\mathrm{df}=992, \mathrm{CMIN} / \mathrm{DF}=1.998, \mathrm{CFI}=0.735$, and $\mathrm{RMSEA}=0.094$. Nine out 25 hypotheses are positive and significant. In particular, one relationship from the personality traits to causation logic is positive and significant, namely, the relationship between conscientiousness and causation logic. The remaining eight relationships which are positive and significant, relate to the relationships of personality traits and the four dimensions of effectuation logic. Specifically, the relationships, which are positive and significant, are as follows: openness, extraversion, and agreeableness to experimentation, conscientiousness to affordable loss, openness, extraversion, and agreeableness to flexibility, and conscientiousness to pre-commitment. These results show that at least three relationships between three dimensions of personality traits, i.e., openness, extraversion, and agreeableness are positively and significantly related to two dimensions of effectuation logic, namely, experimentation and flexibility. It is worth noting that eleven relationships of the model with the 47 items were negatively and non-significantly related to causation logic (three relationships) and the four dimensions of effectuation logic (eight relationships). The three relationships refer to openness, extraversion, and agreeableness to causation logic. The other eight relationships refer to neuroticism to experimentation, openness to affordable loss, conscientiousness and neuroticism to flexibility, and openness, extraversion, agreeableness, and neuroticism to pre-commitment.

Moreover, researchers should consider the nine positive and significant relationships in the model (see Figure 1), namely, agreeableness to experimentation (0.938), conscientiousness to affordable loss (0.872), openness to flexibility (0.814), openness to experimentation (0.756), extraversion to experimentation (0.735), agreeableness to flexibility (0.723), conscientiousness to pre-commitment (0.705), extraversion to flexibility (0.571), and conscientiousness to causation (0.560).

Finally, there are another five relationships that are positively but non-significantly related, namely, the relationships of neuroticism to causation logic, conscientiousness to experimentation, and extraversion, agreeableness, and neuroticism to affordable loss.

Regarding the theoretical contributions of this study, the following can be mentioned:

(a) The five-factor model of personality traits seems to need reshaping or substituting it by the six-factor model or a more advanced model such as the one suggested by Kerr et al. (2017, p. 25) for successful entrepreneurs.

(b) The entrepreneurial process could be an interesting construct to add to the model as the various stages of this process, for example, the third, fourth, and fifth stages have not been empirically tested.

(c) The suggested constructs regarding causation versus effectuation logics, which are measured according to the study by Chandler et al. (2011), seem to receive high reliability and validity in the results.

(d) Other constructs can be added in future research such as entrepreneurship competence and entrepreneurship intention. In addition, a similar model can be tested for social entrepreneurs/social innovators. 


\subsection{Theoretical and Managerial Implications}

Regarding the theoretical implications of this study, future researchers should implement the cognitive-adaptive trait theory discussed in other studies (Matthews 2018), as some core issues of personality traits research remain unresolved.

The findings of this study reveal that effectuation logic is positively and significantly predicted by most of the dimensions of the personality traits openness, conscientiousness, extraversion, and agreeableness, but not neuroticism. However, causation logic is positively and significantly predicted only by conscientiousness. This result should be considered by managers/entrepreneurs in the IT sector, that is, they should think about implementing effectual logic, which may assist them to achieve better performance in their business. It may well be that the companies will achieve better performance when shifting from causation logic to effectuation logic.

\subsection{Limitations}

The question of whether the five-factor model is universal is a tricky one to answer. The question relates to the research methodology. Languages are constructed differently, and sometimes, there is a problem when we translate one word into another language. The underlying meaning can differ, and the subject may perceive the question given to him or her in a way that is different from the intent of the researcher.

This shows the difficulties when constructing questionnaires and collecting surveys across cultural borders. McCrae and Costa (2008), as well as Benet-Martínez and Oishi (2008) and John et al. (2008), have all argued that the five factors in the model can be considered universal and that the traits are at the level of "human nature".

However, there are differing ideas, mainly in those opposing the usage of English language questionnaires that are later translated into the indigenous language. There is also the fact that some words simply do not exist in all languages. Di Blas and Forzi (1999) came across this problem when they researched in Italy. The trait "neuroticism" did not exist in the Italian language. Evidence shows that at least three of the factors are present in almost all cultures, whilst the other two, are commonly found (Cervone and Pervin 2013).

Additionally, there is the argument that traits can be challenging to identify, because of language and cultural barriers, but there is at least a moderate consensus that the five-factor model can be translated across cultures and that traits are universal and can be used as a reasonably good mean of diagnosis and mapping of a person's traits.

Finally, the study has the limitation that it did not include as a dependent construct in the conceptual model the construct of entrepreneurial process or any other relevant constructs such as entrepreneurial intentions and entrepreneurship competence found in other recent studies (Haddad et al. 2021; Joensuu-Salo et al. 2021).

\subsection{Future Research}

The fact that only nine of the tested hypotheses are positive and significant may be an issue that should be taken into consideration in future studies in the field. The findings should be further tested in bigger surveys in different cultures and locations in the IT sector of European countries. The model of personality traits should be upgraded as it is becoming outdated since it was established four decades ago by McCrae and Costa (1987). Innovation and the structures of societies have changed considerably over the decades. Therefore, future researchers should modify the constructs of personality traits and rethink about causation and effectuation constructs. There is already in the literature considerable discussion about new models of personality traits such as implementing the six-factor model of personality traits (HEXACO) (Ashton and Lee 2009; Lee and Ashton 2018), instead of the "big-5" model (Barrick and Mount 1991), which is employed in this study. In addition, IT managers/entrepreneurs are very busy and need to be motivated to reply to a questionnaire. Furthermore, it would be a good idea for future studies to be performed in the manufacturing sector and specifically manufacture ring exporters. Additionally, researchers should investigate further why causation logic is positively and significantly 
predicted by only conscientiousness, while the four dimensions of effectuation logic are positively and significantly predicted by more dimensions of the personality traits of openness, conscientiousness, extraversion, agreeableness, but not neuroticism.

Moreover, future researchers should study decision-making logics in internationalisation (i.e., for effectuation and causation) and how firms use combinations of the two logics in different markets, situations, and internationalisation pathways (Coudounaris 2018).

Researchers should also consider in future studies other constructs for investigation such as sociocultural and economic factors, entrepreneurship and social entrepreneurship, and sustainable development (Méndez-Picazo et al. 2021).

Additionally, recent social innovation has increased due to market failures and government failures to provide necessary products and services. Social entrepreneurs (or social innovators) usually act as agents of change in assuming the responsibility for solving societal problems, and their work consist of gaining access to resources and opportunities, developing capabilities, and forming cohesive networks (Goduscheit et al. 2021). Thus, thousands of successful social innovations propel the need for further relevant models to be developed and be tested.

Finally, soft skills could possibly enter the personality traits construct as the entrepreneurs can possibly react positively to them. Future researchers should test whether soft skills could stimulate entrepreneurs to move on from one stage to the next in the entrepreneurial process (The Difference between Soft Skills and Personality Traits 2021).

Notes: Definitions of causation and effectuation processes and entrepreneur:

Causation is the process in which a goal is identified, and means are allocated with the goal of reaching the target identified. The process includes a strong emphasis on strategic planning.

Effectuation processes occur when an entrepreneur or business leader endeavours in a process where the hypothetical loss in a worst-case scenario is regarded as affordable in their view. They also join strategic alliances to control a situation or a circumstance that is hard to control or predict. They also use pre-commitments as a way of thinking and acting.

According to Metallo et al. (2021), an entrepreneur is "an innovative and creative person who explores the environment for new opportunities and takes advantage of them after proper evaluation" (Metallo et al. 2021, p. 35).

Author Contributions: Conceptualization, D.N.C. and H.G.S.A.; methodology, D.N.C.; software, D.N.C.; validation, H.G.S.A.; formal analysis, D.N.C.; investigation, H.G.S.A.; resources, D.N.C. and H.G.S.A.; data curation, D.N.C.; writing-original draft preparation, D.N.C. and H.G.S.A.; writingreview and editing, D.N.C.; visualization, H.G.S.A.; supervision, D.N.C.; project administration, D.N.C.; and funding acquisition, D.N.C. All authors have read and agreed to the published version of the manuscript.

Funding: This research received no external funding.

Institutional Review Board Statement: Not applicable.

Informed Consent Statement: Not applicable.

Data Availability Statement: The data collected in the web page of Dafnis N. Coudounaris at connect.ee platform (accessed on 9 September 2021).

Conflicts of Interest: The authors declare no conflict of interest.

\section{References}

Allen, Timothy A., and Colin G. DeYoung. 2017. Personality neuroscience and the five factor model. In The Oxford Handbook of the Five Factor Model. Edited by Thomas A. Widiger. Oxford Handbooks Online. Oxford: Oxford University Press. [CrossRef]

Allport, Gordon W. 1937. Personality: A Psychological Interpretation. New York: Henry Holt.

Arvidsson, Henrik G.S., and Dafnis N. Coudounaris. 2020. Effectuation versus causation: A case study of an IT recruitment firm. International Journal of Entrepreneurship 24: 1-13.

Arvidsson, Henrik G.S., Dafnis N. Coudounaris, and Ruslana Arvidsson. 2020. The shift from causation to effectuation of international entrepreneurs: Attitudes and attitude change versus social representations. International Journal of Entrepreneurship 24 : 1-23. 
Ashton, Michael C., and Kibeom Lee. 2009. The HEXACO-60: A short measure of the major dimensions of personality. Journal of Personality Assessment 91: 340-45. [CrossRef]

Avolio, Bruce J., John J. Sosik, Dong I. Jung, and Yair Berson. 2003. Leadership models, methods, and applications. In Handbook of Psychology. Edited by Walter C. Borman, Daniel R. Ilgen, Richard J. Kilmoski and Irving B. Weiner. Hoboken: John Wiley and Sons, Inc., pp. 277-308. [CrossRef]

Baron, Robert A., and Gideon D. Markman. 2018. Toward a process view of entrepreneurship: The changing impact of individual-level variables across phases of new firm development. In Current Topics in Management. Edited by M. Afzalur Rahim, Robert T. Golembiewski and Kenneth D. Mackenzie. New York: Routledge, vol. 9, pp. 45-63.

Barrick, Murray R., and Michael K. Mount. 1991. The big five personality dimensions and job performance: A meta-analysis. Personnel Psychology 44: 1-26. [CrossRef]

Bass, Bernard M., and Ruth Bass. 2008. The Bass Handbook of Leadership: Theory, Research, and Managerial Applications, 4th ed. New York: Free Press.

Bass, Bernard M., and Ralph M. Stogdill. 1990. Bass and Stogdill's Handbook of Leadership: Theory, Research, and Managerial Applications, 3rd ed. New York: Free Press.

Baum, J. Robert, Edwin A. Locke, and Ken G. Smith. 2001. A multidimensional model of venture growth. The Academy of Management Journal 44: 292-303. [CrossRef]

Benet-Martínez, Verónica, and Shigehiro Oishi. 2008. Culture and personality. In Handbook of Personality: Theory and Research. Edited by Oliver P. John, Richard W. Robins and Lawrence A. Pervin. New York: The Guilford Press, pp. 542-67.

Bennis, Warren. 2007. The challenges of leadership in the modern world: Introduction to the special issue. The American Psychologist 62: 2-5, discussion 43-47. [CrossRef]

Berends, Hans, Mariann Jelinek, Isabelle Reymen, and Rutger Stultiëns. 2014. Product innovation processes in small firms: Combining entrepreneurial effectuation and managerial causation. Journal of Product Innovation Management 31: 616-35. [CrossRef]

Botwin, Michael D., and David M. Buss. 1989. Structure of act-report data: Is the five-factor model of personality recaptured? Journal of Personality and Social Psychology 56: 988-1001. [CrossRef]

Bridge, Simon. 2021. Facing uncertainty: An entrepreneurial view of the future? Journal of Management and Organization 27: 312-23. [CrossRef]

Caliendo, Marco, Frank M. Fossen, and Alexander S. Kritikos. 2009. Risk attitudes of nascent entrepreneurs-New evidence from an experimentally validated survey. Small Business Economics 33: 153-67. [CrossRef]

Cattell, Raymond B. 1950. Personality: A Systematic Theoretical and Factual Study, 1st ed. New York: McGraw-Hill.

Cervone, Daniel, and Lawrence A. Pervin. 2013. Personality Psychology, 12th ed. International Student Version. Hoboken: John Wiley and Sons.

Chandler, Gaylen N., Dawn R. DeTienne, Alexander McKelvie, and Troy V. Mumford. 2011. Causation and effectuation processes: A validation study. Journal of Business Venturing 26: 375-90. [CrossRef]

Chetty, Sylvie K., Jukka Partanen, Erik S. Rasmussen, and Per Servais. 2014. Contextualising case studies in entrepreneurship: A tandem approach to conducting a longitudinal cross-country case study. International Small Business Journal 32: 818-29. [CrossRef]

Chetty, Sylvie, Arto Ojala, and Tanja Leppäaho. 2015. Effectuation and foreign market entry of entrepreneurial firms. European Journal of Marketing 49: 1436-59. [CrossRef]

Christensen, Poul R., Majbritt R. Evald, and Kim Klyver. 2011. The effect of human capital, social capital, and perceptual values on nascent entrepreneurs' export intentions. Journal of International Entrepreneurship 9: 1-19.

Ciccarelli, Saundra, and Noland J. White. 2017. Psychology, 5th ed. Boston: Pearson.

Ciszewska-Mlinaric, Mariola, Krzysztof Obloj, and Aleksandra Wasowska. 2016. Effectuation and causation: Two decision-making logics of INVs at the early stage of growth and internationalization? Journal for East European Management Studies 21: 275-97. [CrossRef]

Clark, Lee A. 2007. Assessment and diagnosis of personality disorder: Perennial issues and an emerging reconceptualization. Annual Review of Psychology 58: 227-57. [CrossRef] [PubMed]

Costa, Paul T., and Robert R. McCrae. 1992. Normal personality assessment in clinical practice: The NEO personality inventory. Psychological Assessment 4: 5-13. [CrossRef]

Coudounaris, Dafnis. 1984. Psychic Distance-The Sequential Process of the Firm's Behaviour, in Chapter 5.5: The Export Behaviour of Smaller-Sized Firms Located in the Greater Manchester Area. Master's dissertation, University of Manchester Institute of Science and Technology, Manchester, UK; pp. 221-33. Available online: https:/ /ssrn.com/abstract=2932905 (accessed on 9 September 2021).

Coudounaris, Dafnis N. 2012. Effective targeting of national export promotion programmes for SMEs. International Journal of Globalisation and Small Business 4: 242-83. [CrossRef]

Coudounaris, Dafnis N. 2018. Typologies of internationalisation pathways of SMEs: What is new? Review of International Business and Strategy 28: 286-316. [CrossRef]

Coudounaris, Dafnis N. 2021. The internationalisation process of UK SMEs: Exporting and non-exporting behaviours based on a four forces behavioural model. Review of International Business and Strategy 31: 217-56. [CrossRef]

Coudounaris, Dafnis N., and Henrik G.S. Arvidsson. 2019. Recent Literature Review on Effectuation. Paper presented at the International Marketing Track of the Academy of Marketing Conference 2019, London, UK, July 2-4; pp. 1-18. Available online: https: / / ssrn.com/abstract=3776173 (accessed on 9 September 2021). 
Coudounaris, Dafnis N., and Henrik G.S. Arvidsson. 2021. How Effectuation, Causation and Bricolage Influence the International Performance of Firms via Internationalisation Strategy: A Literature Review. Review of International Business and Strategy. ahead-of-print. [CrossRef]

Coudounaris, Dafnis, Olga Kvasova, Leonidas C. Leonidou, Leyland F. Pitt, and Deon Nel. 2009. Fifteen good years-An analysis of publications in management international review. Management International Review 49: 671-84. [CrossRef]

Cyert, Richard M., and James G. March. 1963. A Behavioral Theory of the Firm. Englewood Cliffs: Prentice-Hall.

Daniel, Elizabeth M., MariaLaura Di Domenico, and Seema Sharma. 2015. Effectuation and home-based online business entrepreneurs. International Small Business Journal 33: 799-823. [CrossRef]

Davidsson, Per. 2005. The Entrepreneurial Process as a Matching Problem. In Annual Meeting of the Academy of Management (65th), 5-10/8/2005. Available online: https:/ / eprints.qut.edu.au/2064/ (accessed on 19 August 2021).

Davidsson, Per, and Jan H. Gruenhagen. 2021. Fulfilling the process promise: A review and agenda for new venture creation process research. Entrepreneurship Theory and Practice 45: 1083-118. [CrossRef]

Derue, D. Scott, Jennifer D. Nahrgang, N. E. D. Wellman, and Stephen E. Humphrey. 2011. Trait and behavioral theories of leadership: An integration and meta-analytic test of their relative validity. Personnel Psychology 64: 7-52. [CrossRef]

Dew, Nicholas, Stuart Read, Saras D. Sarasvathy, and Robert Wiltbank. 2009. Effectual versus predictive logics in entrepreneurial decision-making: Differences between experts and novices. Journal of Business Venturing 24: 287-309. [CrossRef]

Dew, Nicholas, Stuart Read, Saras D. Sarasvathy, and Robert Wiltbank. 2015. Entrepreneurial expertise and the use of control. Journal of Business Venturing Insights 4: 30-37. [CrossRef]

DeYoung, Colin G. 2015. Cybernetic big five theory. Journal of Research in Personality 56: 35-58. [CrossRef]

DeYoung, Colin G., Jacob B. Hirsh, Matthew S. Shane, Xenophon Papademetris, Nallakkandi Rajeevan, and Jeremy R. Gray. 2010. Testing predictions from personality neuroscience: Brain structure and the big five. Psychological Science 21: 820-28. [CrossRef]

DeYoung, Colin G., Lena C. Quilty, Jordan B. Peterson, and Jeremy R. Gray. 2014. Openness to experience, intellect, and cognitive ability. Journal of Personality Assessment 96: 46-52. [CrossRef]

Di Blas, Lisa, and Mario Forzi. 1999. Refining a descriptive structure of personality attributes in the Italian language: The abridged big three circumplex structure. Journal of Personality and Social Psychology 76: 451-81. [CrossRef]

Dimov, Dimo. 2020. Entrepreneurial process: Mapping a multiplicity of conversations. In Research Handbook on Entrepreneurial Behavior, Practice and Process. Edited by William B. Gartner and Bruce T. Teague. Cheltenham: Edward Elgar Publishing.

Dutta, Dev K., Kholekile L. Gwebu, and Jing Wang. 2015. Personal innovativeness in technology, related knowledge, experience, and entrepreneurial intentions in emerging technology industries: A process of causation and effectuation? International Entrepreneurship and Management Journal 11: 529-55. [CrossRef]

Engel, Yuval, Nicoletta Dimitrova, Svetlana N. Khapova, and Tom Elfring. 2014. Uncertain but able: Entrepreneurial selfefficacy and novices use of expert decision logic under uncertainty. Journal of Business Venturing Insights 1-2: 12-17. [CrossRef]

Estonian Startup Database. 2021. Available online: https:/ / startupestonia.ee/startup-database/ (accessed on 24 August 2021).

Eysenck, Hans J. 1960. Behaviour Therapy and the Neuroses: Readings in Modern Methods of Treatment Derived from Learning Theory. Oxford: Pergamon Press.

Fornell, Claes, and David F. Larcker. 1981. Evaluating structural equation models with unobservable variables and measurement error. Journal of Marketing Research 18: 39-50. [CrossRef]

Galkina, Tamara, and Sylvie Chetty. 2015. Effectuation and networking of internationalizing SMEs. Management International Review 55: 647-76. [CrossRef]

Gawel, Aleksandra, and Agnieszka Głodowska. 2021. On the relationship between economic dynamics and female entrepreneurship: Reflections for the Visegrad countries. Administrative Sciences 11: 88. [CrossRef]

Goduscheit, René C., Dmitry Khanin, Raj V. Mahto, and William C. McDowell. 2021. Structural holes and social entrepreneurs as altruistic brokers. Journal of Innovation \& Knowledge 6: 103-11.

Haddad, Ghada, Gloria Haddad, and Gautam Nagpal. 2021. Can students' perception of the diverse learning environment affect their intentions toward entrepreneurship? Journal of Innovation $\mathcal{E}$ Knowledge 6: 167-76. [CrossRef]

Hair, Josef F., William C. Black, Barry J. Babin, and Rolph E. Anderson. 2014. Multivariate Data Analysis. Essex: Pearson Education Limited.

Harms, Rainer, and Holger Schiele. 2012. Antecedents and consequences of effectuation and causation in the international new venture creation process. Journal of International Entrepreneurship 10: 95-116. [CrossRef]

Hu, Li-tze, and Peter M. Bentler. 1999. Cutoff criteria for fit indexes in covariance structure analysis: Conventional criteria versus new alternatives. Structural Equation Modeling: A Multidisciplinary Journal 6: 1-55. [CrossRef]

Jang, Kerry L., Robert R. McCrae, Alois Angleitner, Rainer Riemann, and John W. Livesley. 1998. Heritability of facet-level traits in a cross-cultural twin sample: Support for a hierarchical model of personality. Journal of Personality and Social Psychology 74: 1556-65. [CrossRef] [PubMed]

Jenkins, William O. 1947. A review of leadership studies with particular reference to military problems. Psychological Bulletin 44: 54-79. [CrossRef]

Joensuu-Salo, Sanna, Anmari Viljamaa, and Elina Varamäki. 2021. Understanding business takeover intentions-The role of theory of planned behavior and entrepreneurship competence. Administrative Sciences 11: 61. [CrossRef] 
Johanson, Jan, and Jan-Erik Vahlne. 1977. The internationalisation process of the firm-A model of knowledge, development and increasing foreign markets commitments. Journal of International Business Studies 8: 23-32. [CrossRef]

Johanson, Jan, and Jan-Erik Vahlne. 2009. The Uppsala internationalisation process model revisited: From liability of foreignness to liability of outsidership. Journal of International Business Studies 40: 1412-31. [CrossRef]

John, Oliver P., Laura P. Naumann, and Cristopher J. Soto. 2008. Paradigm shift to the integrative big-five trait taxonomy: History, measurement, and conceptual issues. In Handbook of Personality: Theory and Research, 3rd ed. Edited by Oliver P. John, Richard W Robins and Lawrence A. Pervin. New York: Guilford Press, pp. 114-58.

Jung, Carl G. 1933. Modern Man in Search of a Soul. London: Kegan Paul, Trench, Trubner and Co.

Kerr, Sari P., William R. Kerr, and Tina Xu. 2017. Personality Traits of Entrepreneurs: A Review of Recent Literature. Working Paper 18-047. Boston: Harvard Business School, pp. 1-52. Available online: https://www.academia.edu/41856846/Personality_Traits_of_ Entrepreneurs_A_Review_of_Recent_Literature (accessed on 17 September 2021).

Kotler, Philip. 1991. Marketing Management. Englewood Cliffs: Prentice Hall.

Kraaijenbrink, Jeroen, Tiago Ratinho, Saras D. Sarasvathy, Richard J. Arend, Per Davidsson, Michael Frese, and Anne S. Huff. 2015. Effectuation research: Taking stock and moving forward. Academy of Management Annual Meeting Proceedings 2015: 14288. [CrossRef]

Kvasova, Olga. 2015. The big five personality traits as antecedents of eco-friendly tourist behavior. Personality and Individual Differences 83: 111-16. [CrossRef]

Lam, Wing, and Michael J. Harker. 2015. Marketing and entrepreneurship: An integrated view from the entrepreneur's perspective. International Small Business Journal 33: 321-48. [CrossRef]

Landström, Hans. 1999. The roots of entrepreneurial research. New England Journal of Entrepreneurship 2: 9-20. [CrossRef]

Laskovaia, Anastasiia, Galina Shirokova, and Michael H. Morris. 2017. National culture, effectuation and new venture performance: Global evidence from student entrepreneurs. Small Business Economics 49: 687-709. [CrossRef]

Lee, Kibeom, and Michael C. Ashton. 2018. Psychometric properties of the HEXACO-100. Assessment 25: 543-56. [CrossRef]

Leonidou, Leonidas C., Constantine S. Katsikeas, and Dafnis N. Coudounaris. 2010. Five decades of business research into exporting: A bibliographic analysis. Journal of International Management 16: 78-91. [CrossRef]

Lieberman, David. 2016. The Case against Free Will: What a Quiet Revolution in Psychology Has Revealed about How Behaviour Is Determined, 1st ed. London: Palgrave Macmillan.

Liu, Qian. 2014. Effectuation in Entrepreneurship: A Case Study of Bonusbox. Sweden: KTH.

Mann, Richard D. 1959. A review of the relationship between personality and performance in small groups. Psychological Bulletin 56: 241-70. [CrossRef]

Margolin, Amanda, Keiko Goto, Cindy Wolff, and Stephanie Bianco. 2018. Let's talk food: Elementary school students' perceptions of school and home food environment and the impact of the harvest of the month program on their dietary attitudes and behaviors. International Journal of Child, Youth and Family Studies 8: 154-67. [CrossRef]

Mas-Colell, Andreu, Michael D. Whinston, and Jerry R. Green. 1995. Microeconomic Theory. Oxford: Oxford University Press.

Matalamäki, Marko J. 2017. Effectuation, an emerging theory of entrepreneurship-Towards a mature stage of the development. Journal of Small Business and Enterprise Development 24: 928-49. [CrossRef]

Matthews, Gerald. 2018. Cognitive-adaptive trait theory: A shift in perspective on personality. Journal of Personality 86: 69-82. [CrossRef]

McCrae, Robert R., and Paul T. Costa Jr. 1987. Validation of the five-factor model of personality across instruments and observers. Journal of Personality and Social Psychology 52: 81-90. [CrossRef]

McCrae, Robert R., and Paul T. Costa Jr. 1999. A five-factor theory of personality. In Handbook of Personality: Theory and Research. Edited by Lawrence A. Pervin and Oliver P. John. New York: Guilford Press, pp. 139-53.

McCrae, Robert R., and Paul T. Costa Jr. 2008. The five-factor theory of personality. In Handbook of Personality: Theory and Research. Edited by Oliver P. John, Richard W. Robins and Lawrence A. Pervin. New York: The Guilford Press, pp. 159-81.

McMullen, Jeffery S., and Dimo Dimov. 2013. Time and the entrepreneurial journey: The problems and promise of studying entrepreneurship as a process. Journal of Management Studies 50: 1481-512. [CrossRef]

Méndez-Picazo, Maria-Teresa, Miguel-Angelo Galindo-Martín, and Maria-Soledad Castaño-Martínez. 2021. Effects of sociocultural and economic factors on social entrepreneurship and sustainable development. Journal of Innovation E Knowledge 6: 69-77.

Metallo, Concetta, Rocco Agrifoglio, Paola Briganti, Lorenzo Mercurio, and Maria Ferrara. 2021. Entrepreneurial behaviour and new venture creation: The psychoanalytic perspective. Journal of Innovation \& Knowledge 6: 35-42.

Mets, Tõnis. 2015. Exploring the model of the entrepreneurial process. In Australian Centre for Entrepreneurship Research Exchange Conference 2015. Conference Proceedings, Queensland University of Technology, Adelaide, 3-6 February. Edited by Per Davidsson. Adelaide: Queensland University of Technology, pp. 709-23.

Mets, Tõnis. 2021. The entrepreneurial journey of a global start-up: The case of the open innovation platform GrabCAD. International Journal of Export Marketing 4: 55-71. [CrossRef]

Mets, Tõnis, Mervi Raudsaar, and Kärt Summatavet. 2013. Experimenting social constructivist approach in entrepreneurial processbased training: Cases in social, creative and technology entrepreneurship. In The Experimental Nature of New Venture Creation. Edited by M. Curley and P. Formica. The Springer book series Innovation, Technology, and Knowledge Management; New York: Springer International Publishing, chp. 11. pp. 107-25. [CrossRef] 
Mets, Tõnis, Julia Trabskaja, and Mervi Raudsaar. 2019. The entrepreneurial journey of venture creation: Reshaping process and space. Revista de Estudios Empresariales. Segunda Epoca 1: 61-77.

Moroz, Peter W., and Kevin Hindle. 2012. Entrepreneurship as a process: Toward harmonizing multiple perspectives. Entrepreneurship Theory and Practice 36: 781-818. [CrossRef]

Norman, Warren T. 1963. Toward an adequate taxonomy of personality attributes: Replicated factor structure in peer nomination personality ratings. The Journal of Abnormal and Social Psychology 66: 574-83. [CrossRef] [PubMed]

Nummela, Niina, Sami Saarenketo, Paivi Jokela, and Sharon Loane. 2014. Strategic decision-making of a born global: A comparative study from three small economies. Management International Review 54: 527-50. [CrossRef]

Pfeffer, Lauren, and Mohammad S. Khan. 2018. Causation and effectuation: An exploratory study of New Zealand entrepreneurs. Journal of Technology Management and Innovation 13: 27-37. [CrossRef]

Read, Stuart, and Saras D. Sarasvathy. 2005. Knowing what to do and doing what you know: Effectuation as a form of entrepreneurial expertise. The Journal of Private Equity 9: 45-62. [CrossRef]

Reymen, Isabelle M. M. J., Petra Andries, Hans Berends, Rene Mauer, Ute Stephan, and Elco Van Burg. 2015. Understanding dynamics of strategic decision making in venture creation: A process study of effectuation and causation. Strategic Entrepreneurship Journal 9: 351-79. [CrossRef]

Rogers, Carl R. 1957. The necessary and sufficient conditions of therapeutic personality change. Journal of Consulting Psychology 21: 95-103. [CrossRef]

Rogers, Carl R. 1959. A theory of therapy, personality, and interpersonal relationships: As developed in the client-centered framework. In Psychology: A Study of a Science. Formulations of the Person and the Social Context. Edited by S. Koch. New York: McGraw Hill, vol. 3, pp. 184-256.

Rogers, Carl R. 1967. On Becoming a Person: A Therapist's View of Psychotherapy. London: Constable Publishing.

Sarasvathy, Saras D. 2001. Causation and effectuation: Towards a theoretical shift from economic inevitability to entrepreneurial contingency. Academy of Management Review 26: 243-63. [CrossRef]

Sarasvathy, Saras D. 2009. Effectuation: Elements of Entrepreneurial Expertise. New Horizons in Entrepreneurship. Cheltenham: Edward Elgar Publishing.

Sarasvathy, Saras D., and Nicholas Dew. 2005. New market creation through transformation. Journal of Evolutionary Economics 15: 533-65. [CrossRef]

Schweizer, Roger. 2015. Decision-Making during small and medium-sized enterprises' internationalization-Effectuation vs. causation. Journal for International Business and Entrepreneurship Development 8: 22-41. [CrossRef]

Simpeh, Kwabena N. 2011. Entrepreneurship theories and empirical research: A summary review of the literature. European Journal of Business and Management 3: 1-8.

Smolka, Katrin M., Ingrid Verheul, Katrin Burmeister-Lamp, and Pursey P. M. A. R. Heugens. 2018. Get it together synergistic effects of causal and effectual decision-making logics on venture performance. Entrepreneurship Theory and Practice 42: 571-604. [CrossRef]

Spector, Bert A. 2016. Carlyle, Freud, and the great man theory more fully considered. Leadership 12: 250-60. [CrossRef]

Stogdill, Ralph M. 1948. Personal factors associated with leadership: A survey of the literature. Journal of Psychology 25: 35-71. [CrossRef] [PubMed]

Strohhecker, Jürgen, and Andreas Größler. 2013. Do personal traits influence inventory management performance? The case of intelligence, personality, interest and knowledge. International Journal of Production Economics 142: 37-50. [CrossRef]

The Difference between Soft Skills and Personality Traits. 2021. Available online: https://it.coursesforsuccess.com/blog/2052-thedifference-between-soft-skills-and-personality-traits / (accessed on 9 September 2021).

Top 50 IT Services Companies in Estonia. 2021. Available online: https:/ / themanifest.com/ee/it-services/companies (accessed on 29 August 2021).

Top Software Development Companies in Estonia. 2021. Available online: https://goodfirms.co/directory/country/top-softwaredevelopment-companies/ee (accessed on 24 August 2021).

Trabskaia, Iuliia, and Tõnis Mets. 2021. Perceptual fluctuations within the entrepreneurial journey: Experience from process-based entrepreneurship training. Administrative Sciences 11: 84. [CrossRef]

Tupes, Ernest C., and Raymond E. Christal. 1961. Recurrent Personality Factors Based on Trait Ratings. USAF ASD Tech. Rep. No. 61-97. San Antonio: US Air Force.

Velu, Chander, and Arun Jacob. 2016. Business model innovation and owner-Managers: The moderating role of competition. $R \mathcal{E} D$ Management 46: 451-63. [CrossRef]

Walter, Mischel, and Shoda Yuichi. 1995. A cognitive-affective system theory of personality: Reconceptualizing situations, dispositions, dynamics, and invariance in personality Structure. Psychological Review 102: 246-68. [CrossRef]

Yukl, Gary, Angela Gordon, and Tom Taber. 2002. A hierarchical taxonomy of leadership behavior: Integrating a half century of behavior research. Journal of Leadership and Organizational Studies 9: 15-32. [CrossRef]

Zhao, Hao, and Scott E. Seibert. 2006. The big five personality dimensions and entrepreneurial status: A meta-analytical review. Journal of Applied Psychology 91: 259-71. [CrossRef] [PubMed] 